\title{
Archaeological remains in soil context
}

\author{
Luka Gruškovnjak
}

https://doi.org/10.17234/METARH.2019.2

\author{
Department of Archaeology \\ University of Ljubljana \\ Aškerčeva 2 \\ SI - 1000 Ljubljana, Slovenia \\ luka.gruskovnjak@ff.uni-lj.si
}

The majority of archaeological contexts are located within the soil, therefore processes of soil formation and soil geomorphology play an important role in their formation history. These processes have important implications for the ways of observing and recording as well as understanding and interpreting these contexts. In order to demonstrate their implications a theoretical overview of only a few of those processes which seem most important for archaeology is given in this paper. This is accompanied by hypothetical profile depictions based on the presented theory in order to illustrate in a simplified manner some possible outcomes of the discussed processes reworking the archaeological record. The overview focusses on the difference between sediments and soil horizons and on processes of horizonation, bioturbation and additions or removals of material to or from the soil surface. It demonstrates that the principles of archaeological stratigraphy cannot be universally applied to sites altered by these processes. There the observed layers and contexts may not be the result of depositional events, be it anthropogenic or natural, to which these principles apply. Instead, they may be the result of in situ transformations of original contexts by long-term soil processes. In such cases, the principles of archaeological stratigraphy cannot be applied and the concept of stratigraphic contexts must be replaced with the concept of archaeological remains in soil context. The discussions of processes and accompanying hypothetical depictions in this paper should prove useful to archaeologists in the evaluation of such contexts and in thinking about how they may have been formed. However, the actual formation processes which resulted in the observed archaeological soil context can only be deciphered through interdisciplinary scientific research.

Keywords: archaeological record, soil, horizons, bioturbation, soil geomorphology, stratigraphy, formation processes.

\section{Introduction}

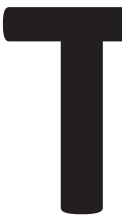

he archaeological record represents a complex intertwinement of past human activities and natural processes involved in its formation history. Post-depositional processes involved in this history are responsible for the fact that the archaeological record almost never corresponds to the original state of deposition by human action but is reworked and transformed through various natural pro- cesses and subsequent human activities which are affecting and changing it up until the moment of its observation as archaeological context (sensu Schiffer 1972: 157; Ib. 1973: 55; Ib. 1983: 676-678). Among the postdepositional processes which almost invariably affect and rework the archaeological record in open-air sites are processes of soil formation and soil geomorphology. The majority of past human activities had taken place 
on the soil surface thus the material remains reflecting these activities were first affected by processes working on the soil surface, then by processes which buried them and consequently by processes working under the surface or within the soil. In all of these three stages processes of soil formation and/or soil geomorphology are involved. They can work to blur or even destroy origi- nal stratigraphy, move and displace artefacts, as well as burry, expose or destroy the archaeological record. Because of these effects processes of soil formation and soil geomorphology are crucial for the understanding of the archaeological record and bear strong implications for the methodology of both its research and recording as well as its final interpretation.

(a)

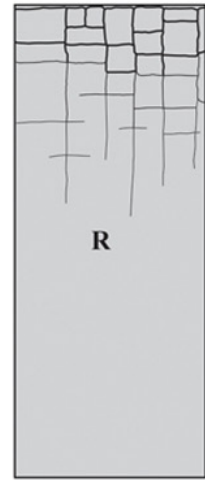

$\mathbf{t}_{1}$

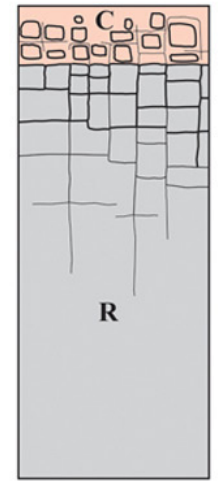

$t_{2}$

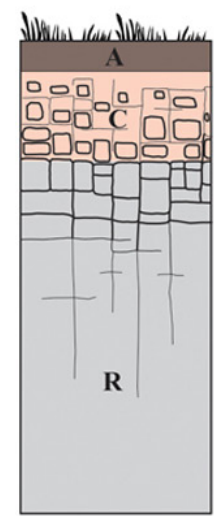

$\mathbf{t}_{3}$

(b)

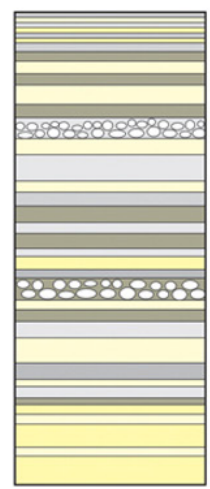

$t_{1}$

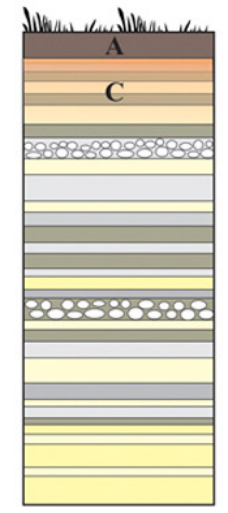

$\mathbf{t}_{2}$

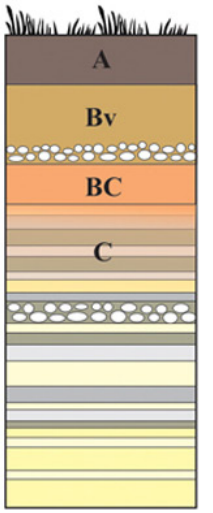

$\mathbf{t}_{3}$

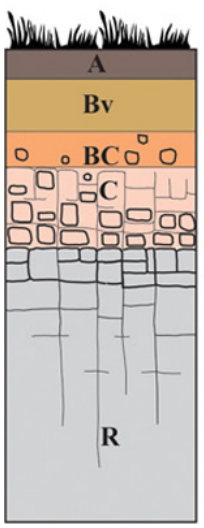

$t_{4}$

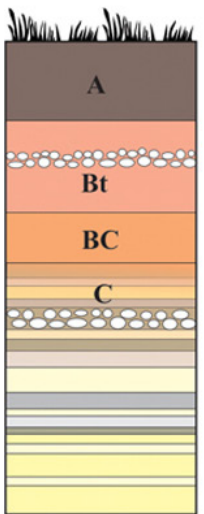

$\mathbf{t}_{4}$

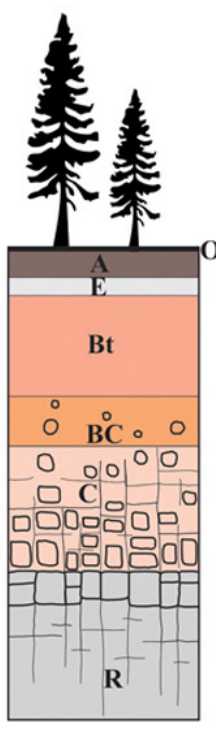

$t_{5}$

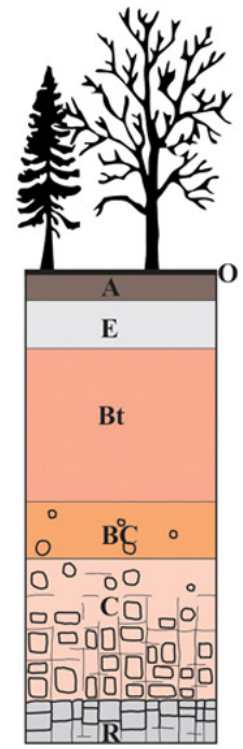

$\mathbf{t}_{6}$

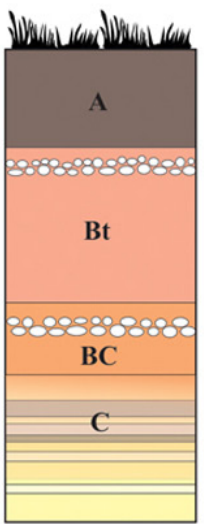

$\mathbf{t}_{5}$

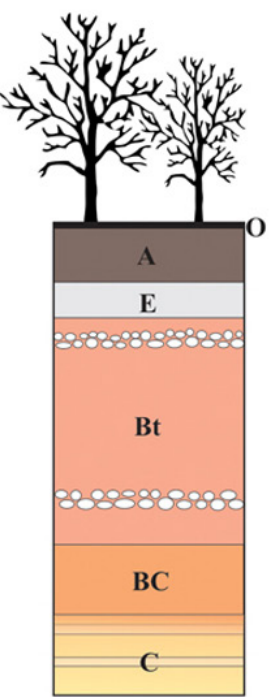

$\mathbf{t}_{6}$

FIGURE 1. Hypothetical profile of soil development by top-down pedogenesis. (a) Soil forming on a rock parent material weathering in situ. The weathered rock or saprolite and the soil forming on it constitute the regolith (drawn after models in Schaetzl and Anderson 2005: Fig. 3.2-3; Weil and Brady 2017: Fig. 2.26, 2.36). (b) Soil forming on a stratified alluvial sedimentary parent material (drawn after models in Straffin et al. 1999: Fig. 2; Mandel and Bettis 2001: Fig. 7.1; Holliday 2004: Fig. 5.5; Weil and Brady 2017: Fig. 2.26). Legend: $t$ = time of observation. 


\section{Layers, sediments, soil horizons and the law of superposition}

Archaeological contexts are located within the mantle of unconsolidated material lying above the bedrock and consisting of different types of layers (sensu Phillips and Lorz 2008) (Fig. 1), recognition of which is crucial for geological, geomorphological, pedological and archaeological research. Because the origin of layers varies greatly it is important to ascertain how they formed in order to interpret them correctly. The archaeological interpretation of layering relies on principles of archaeological stratigraphy (see Harris 1979; Ib. 1989: 29-53; Davies 2015: 3), which can only be applied to layers formed through depositional events. That is why it is crucial to differentiate between layers resulting from deposition and layers developing in situ such as soil horizons to which the stratigraphic law of superposition does not apply (Goldberg and Macphail 2006: 46; Phillips and Lorz 2008: 144-146). The mantle of weathered rock material formed in situ, i.e. the regolith, can be divided into several layers which are gradually and simultaneously forming in place (Gregorich et al. 2001: 297; Huggett 2007: 89; Anderson and Anderson 2010: 162-163), therefore the law of stratigraphic superposition does not apply to them. As the constituents of the regolith are removed, transported and then deposited at another location by natural forces and processes or through human action we are dealing with the transported regolith or clastic sediments (Stein 1987: 339; Harris 1989: 47-48; Schaetzl and Anderson 2005: 32, 171; Huggett 2007: 89; Howard 2017: 3, 43). To all layers of natural or anthropogenic sediments deposited in this manner, the principle of stratigraphic superposition does apply.

Both rock weathered in situ and natural or anthropogenic clastic sediments located on the surface or near the surface represent parent materials in which soils form (Fig. 1). All soils are composed of a different number of horizons which are all genetically linked because they interdependently form through the pedogenic alteration of parent materials into layers with distinct physical, chemical and biotic properties (Holliday 1990: 527; Tandarich et al. 2002: 338; Schaetzl and Anderson 2005: 36; Phillips and Lorz 2008: 145; Vrščaj 2013: 318, 321; Vidic et al. 2015: 19, 41). Because soil horizons are genetically linked they do not reflect a sequence of deposition, therefore the law of stratigraphic superposition does not apply to them (Finkl 1980: 171; Cremeens and Harth 1995: 26; Holliday 2004: 83).

Because soils represent a continuum in the landscape and a background to any human activity the majority of archaeological contexts we observe are located within the soil or on the soil surface (Goldberg and Macphail 2006: 42). Consequently, pedogenic and geomorphic processes involved in soil formation are also crucial in the formation of archaeological record itself. Therefore, some degree of their understanding and recognition in the field is needed in archaeological research.

\section{Soil formation and soil geomorphology}

Processes of soil formation and soil geomorphology are important for the understanding of the archaeological record because they can blur or even destroy sediment stratigraphy, cause artefact movement, as well as contribute to the burial, exposure or destruction of the archaeological record.

Processes involved in soil formation or pedogenesis may be divided into two main groups. The first group is represented by processes causing horizonation, while the second group is represented by processes countering it and causing haploidization or homogenization. Horizonation refers to pro-anisotropic conditions, factors and processes causing anisotropy (order, sorting, non-randomness) by altering parent material into a soil profile with genetic horizons. Haploidization or homogenization refers to pro-isotropic conditions, factors and processes causing isotropy (disorder, chaos, randomness) by countering horizonation, causing profile simplification, and destruction of soil horizons. In the latter, especially pedoturbation or soil mixing processes, as well as geomorphic processes of erosion and deposition are involved (Johnson and Watson-Stegner 1987: 356-357, tab. 1-2; Blume et al. 2016: 294). However, from an archaeological point of view, both horizonation and pedoturbation can be seen as mixing processes, because archaeology is interested in the original state of deposition and both processes, no matter whether they are working towards order or disorder, cause mixing of the original state and thus blurring or destruction of primary depositional contexts (Holliday 2004: 263). In the case of horizonation, only the fine fraction is affected, while pedoturbation also affects the coarse fraction.

\section{Horizonation}

Horizonation works from the top down and is time progressive in terms of depth it reaches and the strength of differentiation of the profile (Johnson and WatsonStegner 1987: 349; Almond and Tonkin 1999: 2; Weil and Brady 2017: 88, Figs. 2.36, 2.39). It effectively causes pedogenic layering recognition of which is crucial dur- 
ing archaeological observations because soil horizons which are not recognized as such may erroneously be interpreted as a stratigraphic sequence of depositional layers (Fig. 9c: I). This will cause a misunderstanding of site's formation processes and lead to errors in the interpretation of depositional events at the site (e.g. Phillips and Lorz 2008: 152). Additionally, in the case of stratified parent materials, horizonation causes progressive destratification of the original depositional layers. At an archaeological site (Fig. 2), artefacts which were once part of depositional layers will lose their original stratigraphic context and become part of soil context. Some data about the original relative stratigraphy may, in this case, be preserved only in the positions of artefacts within the soil ${ }^{1}$. The original stratigraphy of a site will only be preserved under the lower boundary of the pedon, where it has not yet been subjected to intensive changes through pedogenic processes (e.g. Wilkinson 1990: 91-92, Fig. 2).

\section{Pedoturbation: bioturbation}

Pedoturbation is usually described as a mixing of materials through different processes ${ }^{2}$. However, these may not only cause mixing (pro-isotropic processes) but also sorting (pro-anisotropic processes) of materials. Whether pedoturbation works towards mixing or sorting is often dependent on the size fraction observed, as many forms of pedoturbation mix the fine fraction while sorting and causing order within the large fraction. When coarse fragments, such as stones and artefacts, are not included in the mixing process this may cause the formation of subsurface layers, as in the case of bioturbation (Fig. 3), or surface covers, as in the case of cryoturbation and argilliturbation, consisting of coarse fragments (Wood and Johnson 1978; Johnson et al. 1987: 278-279; Schaetzl and Anderson 2005: 240; Blume et al. 2016: 308; Fey and Schaetzl 2017: 10). Pedoturbation processes have very strong implications for archaeology. On one hand, the mixing of the fine fraction can cause blurring or even total obliteration of original sediment stratigraphy and its transformation into a single massive layer. On the other hand, it implies that coarse fragments ${ }^{3}$ such as stones and artefacts are not static elements of the sedimentary or soil matrix but may be translocated, mixed or

\footnotetext{
${ }^{1}$ Contrary to the view that archaeological stratification may exist without artefacts (Harris 1979: 112).

${ }^{2}$ For a list and description of different forms of pedoturbation processes see Schaetzl and Anderson 2005: 245-294, Tab. 10.1 and for some of their effects on archaeological sites see Wood and Johnson 1978.
}

sorted within it.

Bioturbation is perhaps the most important group of pedoturbation processes to be considered in archaeology as it is the most ubiquitous. It involves biomechanical action of living organisms, animals (faunalturbation) and plants (floralturbation), which can produce and destroy soil horizons as well as other types of layers by causing the movement of fine soil fractions as well as coarse fragments upward, downward or laterally (Wood and Johnson 1978: 318-333; Johnson 2002: 7; Schaetzl and Anderson 2005: 247-262). The main product of bioturbation is the formation of the so-called biomantle, which is the topsoil layer or A horizon formed primarily through processes of bioturbation. Because biomantles are essentially ubiquitous over Earth's subaerial substrates the concept of the biomantle and processes involved in its formation holds huge implications for archaeology (Johnson 1993: 71-76; Johnson 2002; Johnson et al. 2005a: 38, tab. 1; Johnson et al. 2005b, 16, 19, 21-22, tab. 1; Goldberg and Macphail 2006: 59). Namely, most past human activities took place on the surface of this highly energetic and dynamic topsoil layer and were in different ways also involved in its formation. Thus, most open-air archaeological sites had originally formed on the surface of the biomantle and/or were subsequently subjected to the processes of its formation and strongly affected by them throughout their formation history.

From an archaeological perspective, some of the most important possible effects of faunalturbation are the burial of surface materials, the downward sinking of coarse fragments, the obliteration of features within the biomantle and the translocation of coarse fragments through burrows (Figs 3-4). Burial is achieved primarily through surface mounding, caused by different types of fauna, as well as the gradual downward sinking of coarse fragments through the biomantle. Gravitational sinking results from a combination of burrowing around the coarse fragments, collapsing of the burrows and constant transfer of fine fraction to the surface. Earthworm activity is one of the main reasons for this process in temperate zones and when achieved primarily through earthworm activity the effect is pro-anisotropic. At the maximal depth of faunalturbation, coarse fragments

\footnotetext{
${ }^{3}$ For a list of pedoturbation processes which can move coarse fragments see Schaetzl and Anderson 2005: Tab. 10.2.
} 


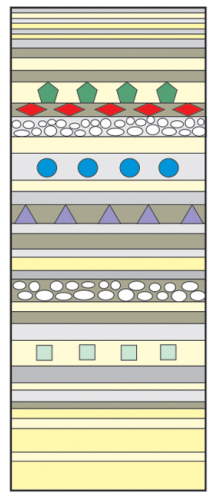

$\mathbf{t}_{1}$

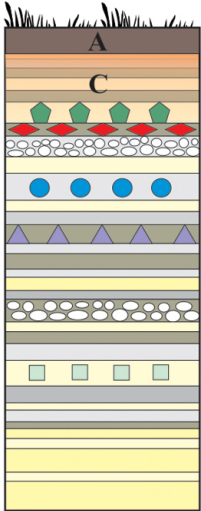

$\mathbf{t}_{2}$

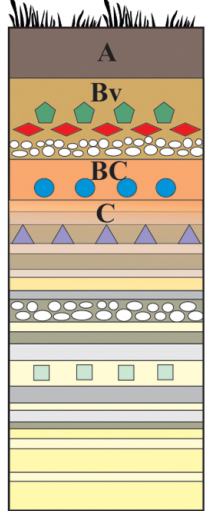

$\mathbf{t}_{3}$

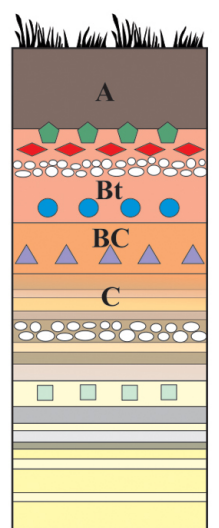

$\mathbf{t}_{4}$

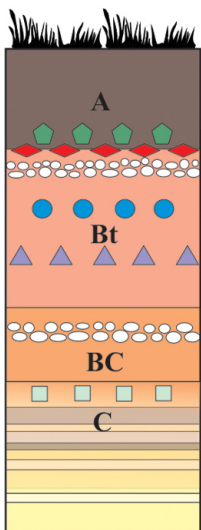

$\mathbf{t}_{5}$

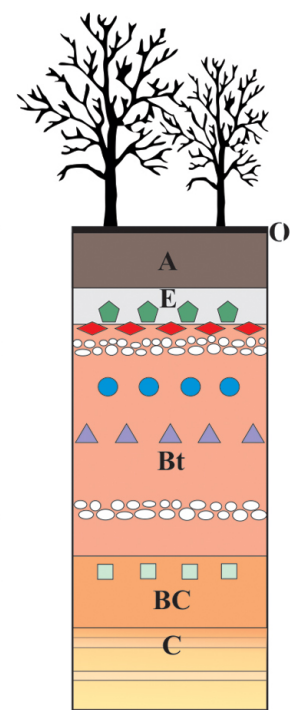

$\mathbf{t}_{6}$

$$
a_{1}=\square \quad a_{2}=\triangle \quad a_{3}=\bigcirc \quad a_{4}=-a_{5}=
$$

FIGURE 2. Hypothetical profile of stratified parent material from Fig. 1a, with added archaeological artefacts. This case represents a visualization of a stratified multiperiod archaeological site, which is being progressively destratified through pedogenesis. With the formation of soil horizons, artefacts lose their initial stratigraphic context and are becoming part of soil context, with horizons which are genetically linked and contemporaneous. The only relative stratigraphic data preserved are represented in artefact positions within the soil. Legend: $t=$ time of observation; $a=$ artefacts of different periods.

become concentrated within the so-called stone- and/ or artefact-lines or layers, which give a false impression of a depositional event, paleosurface and/or cultural layer (Fig. 3). Therefore, artefacts of different time periods which had been exposed to the process of sinking for long enough to reach the terminal depth can be mixed within such layers, while artefacts which have not yet reached the terminal depth may retain their relative superposition (Atkinson 1957: 221-225; Wood and Johnson 1978: 321-328; Rolfsen 1980: 119; Stein 1983: 280; Johnson 1989; McBrearty 1990; Johnson and Balek 1991; Vermeersch and Bubel 1997: 126; Leigh 1998; Balek 2002: 43; Johnson 2002: 8, 24, figs. 5A, 6-9; Peacock and Fant 2002; Van Nest 2002, 62-63, 77, 79; Canti 2003: 139-142; Johnson et al. 2005a: 40, tab. 1; Johnson et al. 2005b, 21-22, tab 1). Simultaneously, earthworm activity causes thorough mixing of the fine fraction resulting in blurring or obliteration of different types of layers and features. At an archaeological site earthworm activity may for example completely destroy original living surfaces and associated anthropogenic layers, upper parts of cut features (pits, ditches etc.) (Fig. $3: t_{3}-t_{6}$ ) and buried soils under smaller mounds and embankments
(Atkinson 1957: 225-227; Langmaid 1963; Rolfsen 1980: 117; Stein 1983: 280; Canti 2003: 142; Tryon 2006: 199). Abandoned occupational sites with their abundance of organic materials on which earthworms feed may even be preferred locations of their activity, while trampled and compacted ground at such sites may also result in the intensification of burial through earthworm casting. It is important to note, that burial and sinking effects, while very variable, can be achieved quite rapidly, as terminal depth of sinking can already be reached within only two decades ${ }^{4}$ (Stein 1983: 280; Vermeersch and Bubel 1997: 126-127; Canti 2003: 141-142; Hanson et al. 2009: 243-245).

The activities of larger burrowing animals can also contribute to the downward sinking of coarse fragments, while they also oppose it and their influence on the movement of coarse fragments within the soil is much more pro-isotropic (Fig. 4). The activities of animals such

\footnotetext{
${ }^{4}$ The speed of sinking is fast enough that its influence must already be considered in criminal investigations of 6-12 months old events (Hanson et al. 2009: 245).
} 


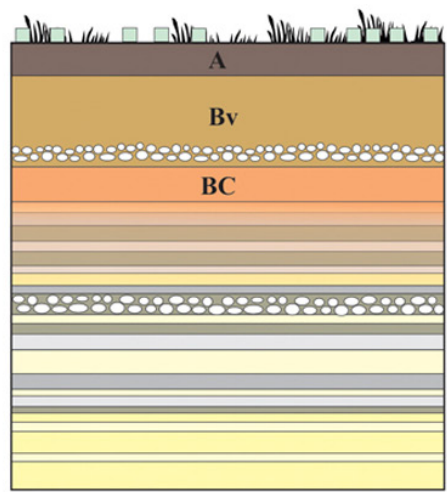

$\mathbf{t}_{1}$

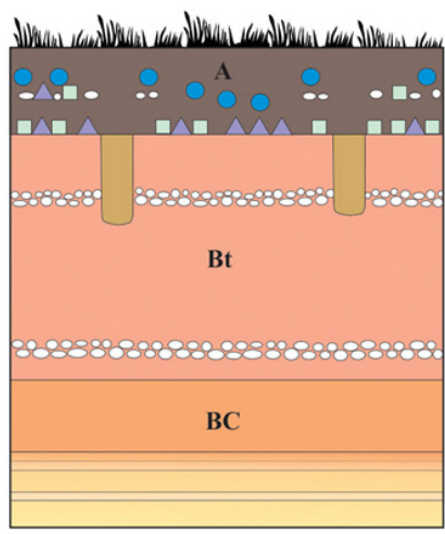

$t_{4}$

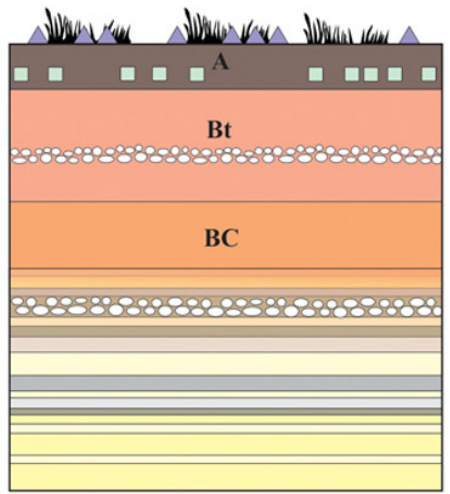

$\mathbf{t}_{2}$

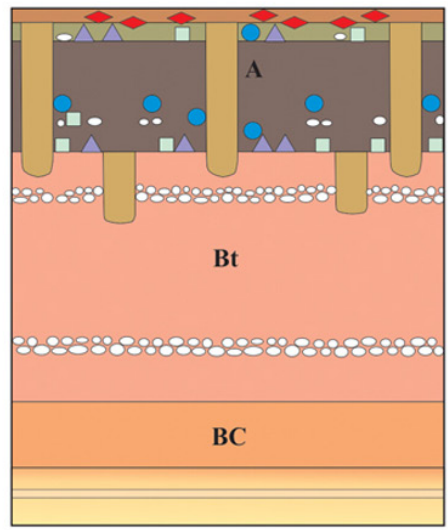

$\mathbf{t}_{5}$

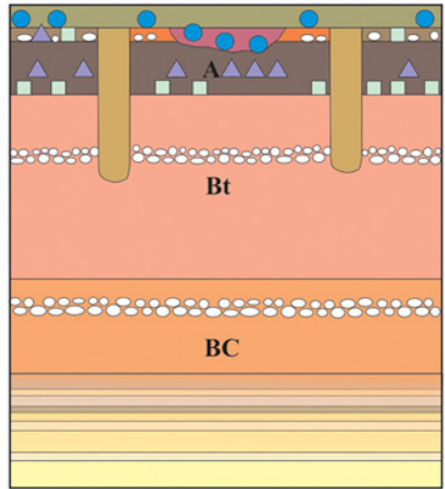

$\mathbf{t}_{3}$

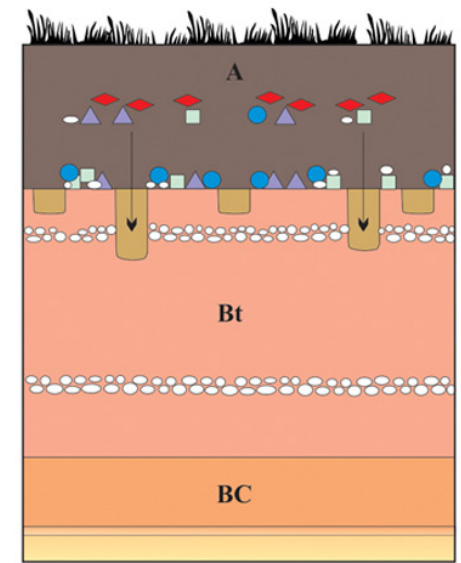

$t_{6}$
$a_{1}=\square$
$a_{2}=\Delta$
$a_{3}=$
$a_{4}=$

FIGURE 3. Hypothetical profile of a multiperiod archaeological site subjected to the process of biomantle formation. At the first time of observation (t1), artefacts of the first period (a1) are deposited on the natural soil surface. By the t2, these have sunk down into the A horizon but have not yet reached terminal depth, while a2 artefacts are deposited on the surface. At the 3 , some settlement remains are visible, consisting of post hole pits, earthen floor and a fireplace in the house interior, an anthropogenic layer on the house exterior and a destruction layer covering and burying the remains. By this time, al artefacts have already sunk to the terminal depth, while a2 artefacts have not and thus still preserve some relative stratigraphic relation with a1 artefacts. Because the construction of the house involved digging into the soil, some of the a1 and a2 artefacts have been translocated to the surface and mixed into cultural layers of the third period (anthroturbation). By the t4, the layers and features of the third period which were present on the surface or within the A horizon have been thoroughly mixed and obliterated by bioturbation. The artefacts connected with the occupation of the house (a) have sunk into the A horizon and their position in the profile no longer corresponds to the original occupation surface. Beneath them, a1 and a2 artefacts are mixed within the artefact line or layer. Because of anthroturbation some of them are also located higher within the profile. At $\mathrm{t} 5$, some settlement remains of the fourth period (a4) are visible on the surface. These are represented with artefacts, post holes, anthropogenic layer and a destruction layer covering and burying the remains. The az artefacts have sunk deeper but have not yet reached terminal depth, thus still preserving some relative stratigraphic relations to the older artefacts which are already mixed at the bottom of the A horizon. Due to anthroturbation some older artefacts were translocated and mixed into the anthropogenic layer of this period. At t6, the layers and features of the fourth period (a4) have again been thoroughly mixed and obliterated within the A horizon. Artefacts of the fourth period (a4) have sunk into the A horizon and no longer correspond to the original occupation surface. At the bottom of the A horizon a1-3 artefacts are mixed within the artefact line or layer, while due to anthroturbation some of them are also located higher within the profile, near to a 4 artefacts. With time some of these artefacts may sink into cut features and become incorporated into their fill, thus complicating the original context of the site even further. The only remains preserved of the houses in the third and fourth period are parts of post holes which reach into the $B$ horizon and have thus not been subjected to intense bioturbation. A typical site subjected to this kind of formation processes will thus consist of shallow pit remains preserved only within the B horizon, of a naturally formed layer of translocated and mixed artefacts belonging to different occupation periods located just above the B horizon or at the bottom of the A horizon, and some possible levels of artefacts within the A horizon which have not jet sunk to the terminal depth. All anthropogenic layers, occupation surfaces and shallow features such as fireplaces will be absent. Legend: $\mathrm{t}=$ time of observation; $\mathrm{a}$ = artefacts of different periods. 
as rodents, moles, rabbits, badgers, foxes, wild boars etc., who burrow, make dens, excavate, scratch or in other ways impact the soil, as well as the activities of humans, all cause different types of disturbances including coarse fragment movements and rearrangements (Dunwell and Trout 1999; Johnson et al. 2005b: 20-22, tab. 1 ). The type of movement and the size fraction of fragments affected depends on the species, size and type of burrowing or excavating behaviour of the animal in question. Because of their activity, coarse fragments are subjected to movement in the upward and downward direction as well as laterally (Rolfsen 1980: 116; Bocek 1986; Johnson et al. 1987: 283-284; Balek 2002: 42, 46; Araujo and Marcellino 2003).

Coarse fragments, including archaeological artefacts, can also be mixed within the soil and brought to the surface through tree-uprooting or treethrow (Fig. 5) which

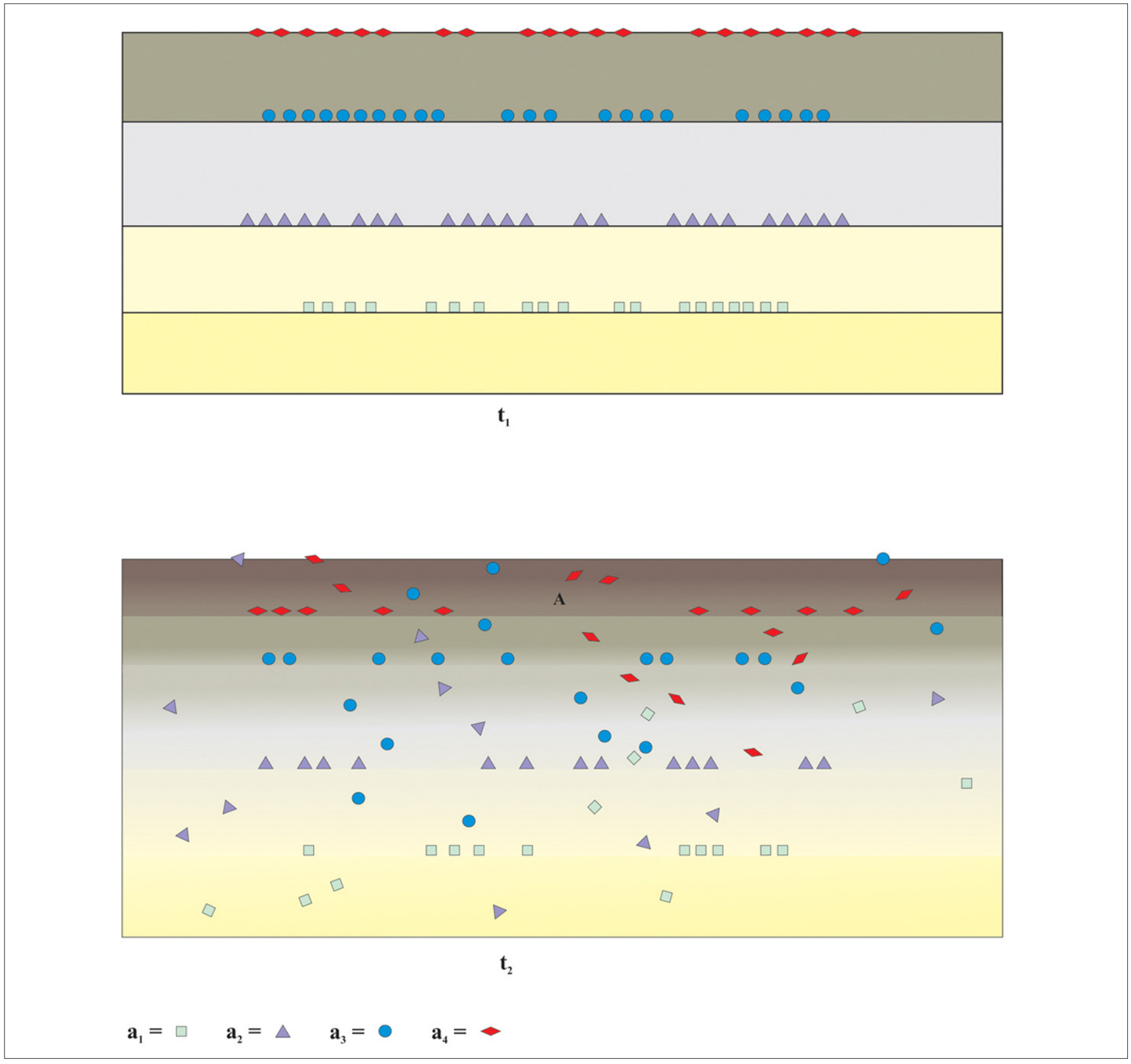

FIGURE 4: Hypothetical example of archaeological stratigraphy affected by faunalturbation by small burrowing mammals. Artefacts which were located on the surface $\left(\mathrm{t} 1, \mathrm{a}_{4}\right)$ have sunk to the bottom of the newly formed A horizon. All levels have been disturbed and artefacts translocated in all directions. The artefact densities of original distributions have decreased and parts of original associations have been lost. However, the depth distribution of artefacts still indicates the original deposition levels of each period. Due to mixing the boundaries between layers have started to blur (created after the models in Johnson et al. 1987: Figs. 12-13; Araujo and Marcelino 2003: Figs. 2, 8-11; Schaetzl and Anderson 2005: Fig. 13.59). 


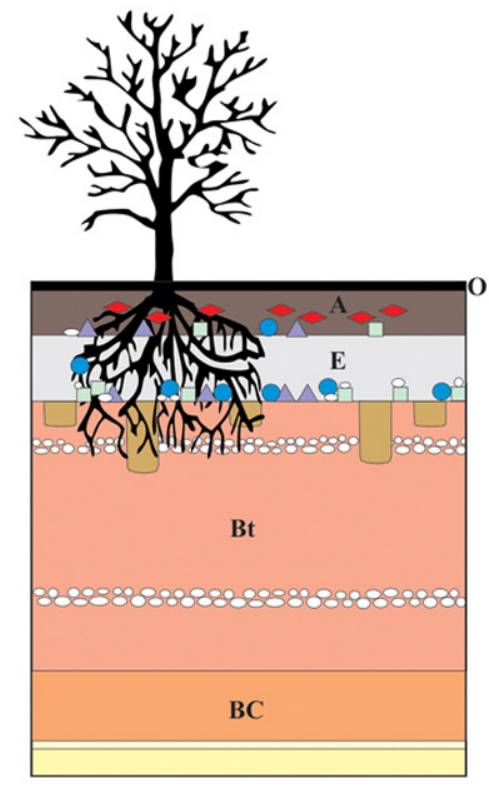

$t_{1}$

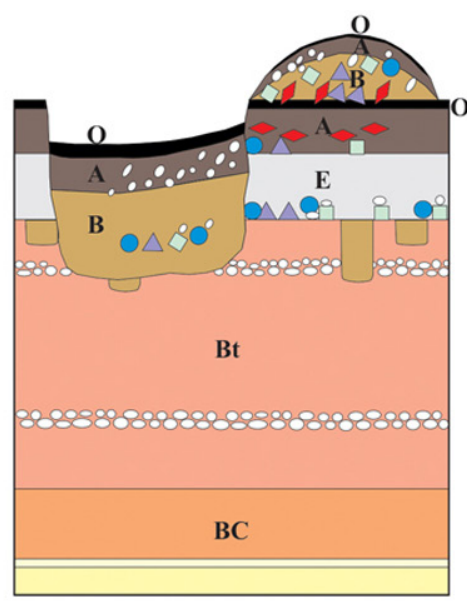

$\mathbf{t}_{4}$

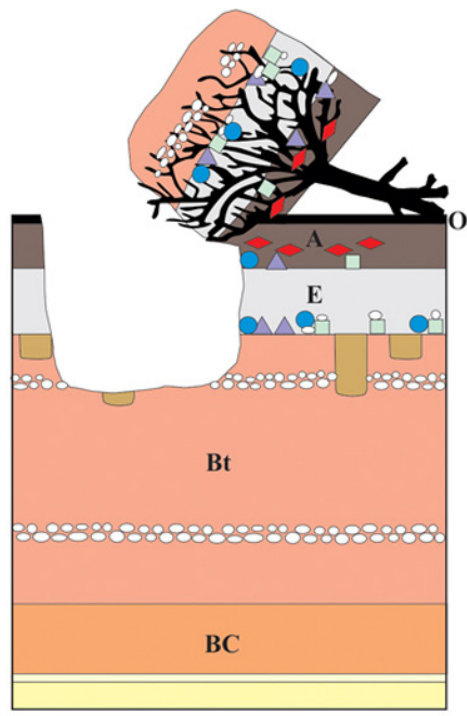

$\mathbf{t}_{2}$

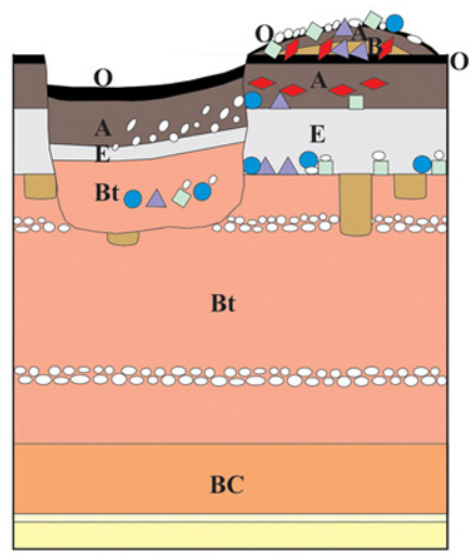

$\mathbf{t}_{5}$

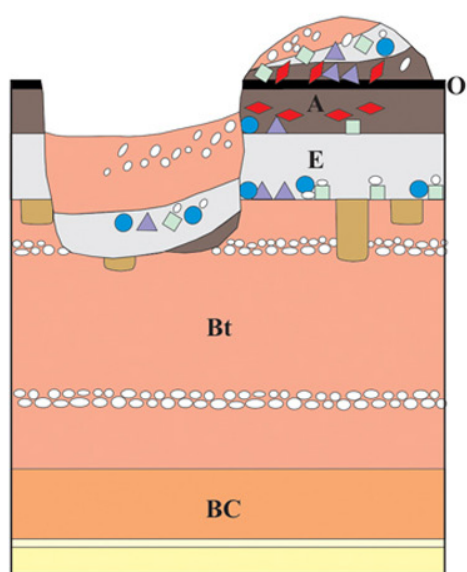

$\mathbf{t}_{3}$

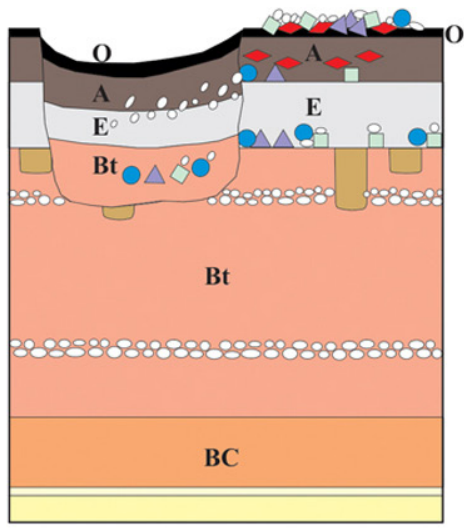

$\mathbf{t}_{6}$

$a_{1}=\square \quad a_{2}=\triangle \quad a_{3}=\bullet \quad a_{4}=\bullet$

FIGURE 5. Hypothetical example of treethrow effects on the archaeological record. A tree growing on an archaeological site (t1) is uprooted, displacing a larger volume of the soil (t2) and thus damaging and reworking a part of the archaeological record. Part of the volume falls into the pit and part on the ground surface next to it, forming a characteristic pit and mound microtopography (t3). In this simplified hypothetical example, soil horizons are inverted while the artefacts are translocated and mixed. New soil formation begins both in the pit fill and mound material (t4-t6) (shown in a simplified manner, for concrete examples see Schaetzl 1986, fig. 2-3; Schaetzl and Follmer 1990: 3; Šamonil et al. 2013, fig. 5; Šamonil et al. 2016, fig. 2. Note that the scenario also has implications for anthropogenic mounds, pits and similar features.). With time the mound is eroding while the pit is filling with materials from its surroundings ( $\mathrm{t} 5 \mathrm{-t} 6)$. The erosion of the mound leads to the formation of a concentration of artefacts and other coarse fragments on the surface in form of a lag concentrate (t6) (created after models in Schaetzl et al. 1989: Fig. 1-2; Norman et al. 1995: Fig. 2; Schaetzl and Follmer 1990: Figs. 1, 4).

represents the most studied process of floralturbation also referred to as arboturbation. This is a process in which the tree falls together with most of its larger roots intact. This can disrupt and move a considerable volume of soil or sediment material, causing bending, mixing or even complete inversion of soil horizons or stratified layers. Furthermore, treethrow is also an important cause for bringing coarse fragments including very large rocks 


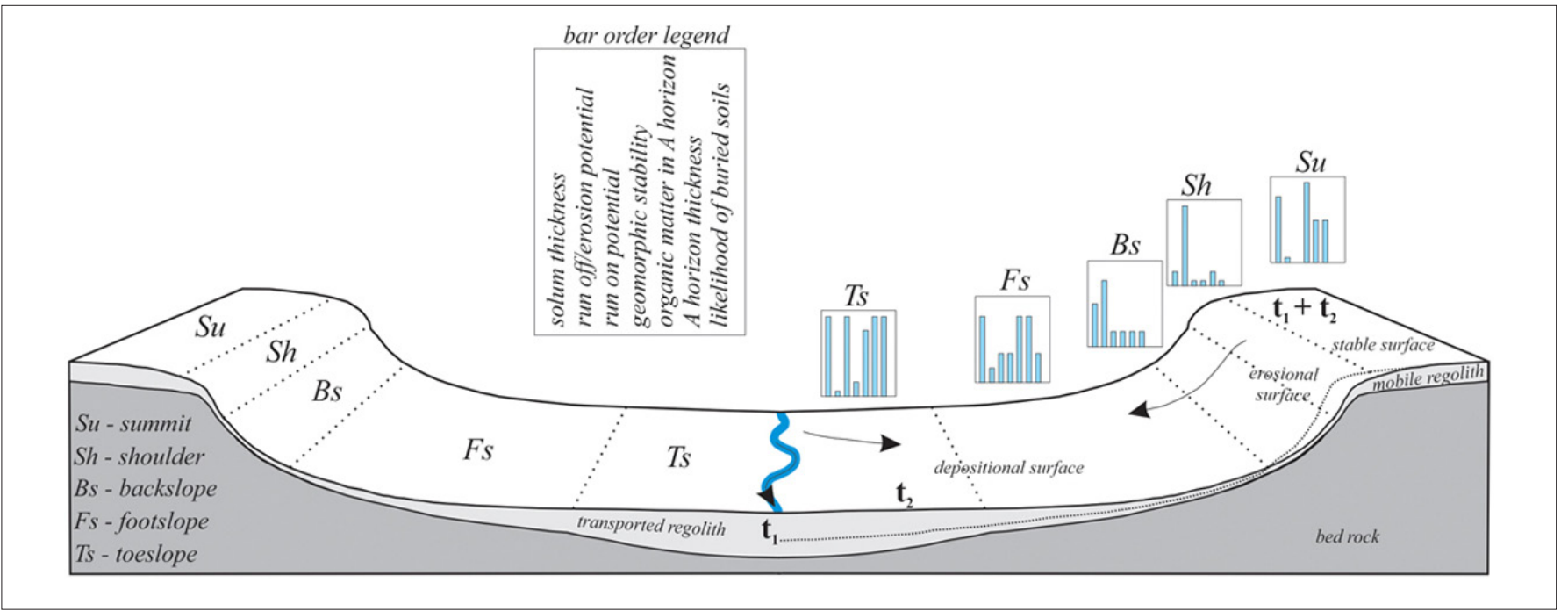

FIGURE 6. Model of five slope elements in an open drainage catena. The bars indicate relationships between soil characteristics and geomorphic processes along the slope. Arrows indicate general directions of sediment transport by water and gravity (colluviation downslope, bedload and suspended load downstream, and overbank deposition of suspended load or alluviation). The time transgressive nature of geomorphic surfaces (stable, erosional and depositional) is indicated on the left by the dotted and full-line and the position of each surface at time1 (t 1 ) and time2 (t2) (created after the models in Schaetzl and Anderson 2005: Figs. 13.2, 13.4, 13.10; Schaetzl 2013: Fig. 3).

and stones to the surface. In all forests uprooting is a very common and widespread process due to either catastrophic events influencing the whole forest or ubiquitous and constant uprooting of individual trees. Thus, through a longer time span this temporally and spatially discontinuous process may encompass a very large part of the landscape (Schaetzl 1986: 181; Schaetzl et al. 1989: 5-7, tab. 2; Schaetzl et al. 1988: 166-167; Schaetzl and Anderson 2005: 243-244). For central European beech forests it is generally estimated that a third of all trees die due to uprooting, that the whole forest area is submitted to this process within the time span of 9001400 years and that at the same location it is repeated every 500-3000 years (Šamonil et al. 2013: 127; Šamonil et al. 2015: 589; Šamonil et al. 2016: 55-56). This has some strong implications for archaeology. Namely, it seems that many archaeologists presume that archaeological sites in forested areas are well preserved because they were not subjected to cultivation ${ }^{5}$. However, whole forested areas may be naturally "ploughed" and disturbed within the span of approximately two millennia. Among other consequences, this also leads to increased concentrations of coarse fragments on the surface, allowing detection with the surface survey.

\footnotetext{
${ }^{5}$ At the same time, it is also often presumed that areas not subjected to modern cultivation somehow escaped anthropogenic reworking and disturbance despite, among other things, the fact that much land has been taken out of agricultural production in the recent past (Padgett 1994: 37).
}

\section{Geomorphic processes}

Geomorphic processes strongly influence both soil and archaeological record formation. Therefore the ability to identify areas of erosion, transport and deposition of material (alluvial or colluvial) as well as the areas of no erosion and deposition is a prerequisite for the study of any landscape as well as of soils and archaeological record within it. The interplay between geomorphic and pedogenic processes, which is in large part determined by topography (Fig. 6), will determine the nature, completeness and variability of the archaeological record both on the scale of the landscape as well as individual sites (Ferring 1986; Waters and Kuehn 1996: 485; Mandel and Bettis 2001: 181-183; Barton et al. 2002: 186-187; Stafford and Creasman 2002; Goldberg and Macphail 2006: 59-60, 73).

On stable surfaces (Fig. 6), the archaeological record will be most strongly subjected to pedogenic processes causing horizonation (Fig. 2) since soils in such locations are deep and well developed. In the absence of anthropogenic sediment depositions, the burial of the archaeological record on such surfaces will be shallow and primarily caused by bioturbation. Because of the low rate or even absence of sedimentation, the remains of different phases of past human activities such as occupation will be mixed in the form of a palimpsest and concentrated within the A horizon or in the stone-line at its bottom (Fig. 3). In these circumstances, higher artefact 
(a) rate of sedimentation < rate of pedogenesis

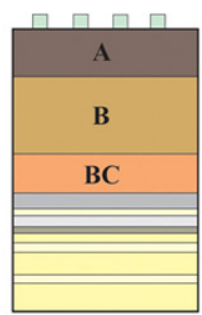

$\mathbf{t}_{1}$

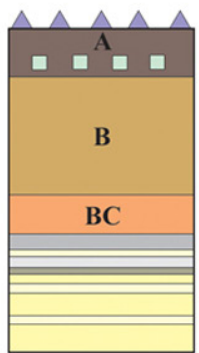

$\mathbf{t}_{2}$

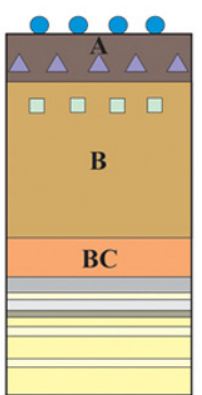

$\mathbf{t}_{3}$

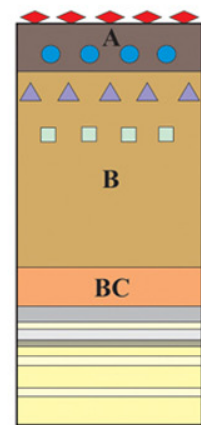

$\mathbf{t}_{4}$

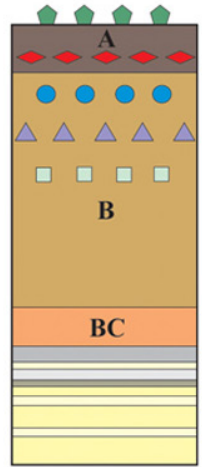

$\mathbf{t}_{5}$

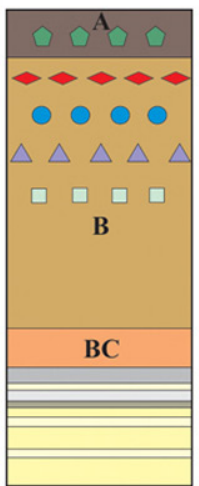

$\mathbf{t}_{6}$

$$
a_{1}=\square \quad a_{2}=\triangle \quad a_{3}=\bullet \quad a_{4}=\bullet \quad a_{5}=\bullet
$$

(b) rate of sedimentation $=$ rate of pedogenesis

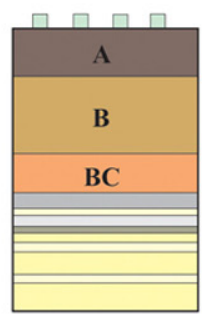

$\mathbf{t}_{1}$

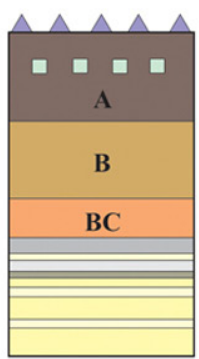

$\mathbf{t}_{2}$

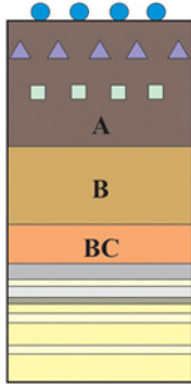

$\mathbf{t}_{3}$

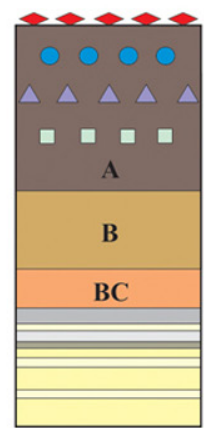

$\mathbf{t}_{4}$

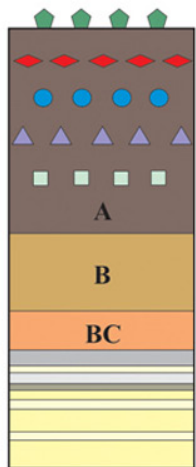

$\mathbf{t}_{5}$

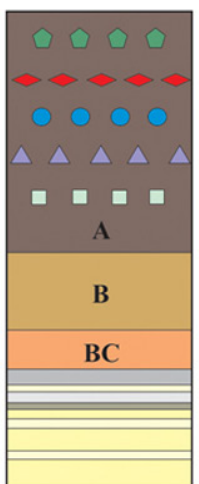

$\mathbf{t}_{6}$

FIGURE 7. Hypothetical profiles of upbuilding soil with archaeological remains of different periods. (a) Developmental upbuilding. Artefacts deposited in different periods as well as sediment additions (natural or anthropogenic) first become incorporated into the $A$ horizon and later into the B horizon. All levels of deposition will with time become part of the upbuilding B horizon and will be discernible only through the relative stratigraphic relations preserved in artefact positions within the overthickened B horizon. (b) Cumulisation. Artefacts deposited in different periods, as well as sediment additions (natural or anthropogenic) are becoming part of the upbuilding A horizon. The levels of deposition will be discernible only through positions of the artefacts within the overthickened $A$ horizon. Legend: $t=$ time of observation; $a=$ artefacts of different periods (created after the model in Holliday 2004: Fig. 2-4; Schaetzl and Anderson 2005: Fig. 12.78; Lowe and Tonkin 2014: Fig. 1-2).

densities and unclear spatial patterns can be expected (Ferring 1986: 264-265; Leigh 1998; Mandel and Bettis 2001: 175, 185; Balek 2002; Van Nest 2002; Holliday 2004: 142-143).

On erosional surfaces (Fig. 6), the influence of removals on the archaeological record will be mainly conditioned by the strength of erosional processes. Erosion caused by surface runoff and wind action gradually lowers the surface and soils are consequently shallow and weekly developed. Because of soil erosion, the borders of soil horizons constantly migrate downward as the $A$ horizon gradually develops in the previous $\mathrm{B}$ horizon and the $\mathrm{B}$ horizon in the unmodified parent material below (Fig. 8b). Such soil erosion may gradually destroy buried archaeological layers while constant removal of fine soil particles causes the surface to become enriched with coarse fragments in the form of surface lag concentrate or carpetolith (Fig. $8 b: t_{2}-t_{3}, t_{5}-t_{6}$ ). In such circumstances, the archaeological artefacts from different phases of past human activities will be concentrated and mixed in the form of a palimpsest on the surface. Thus high densities of surface artefacts and unclear spatial patterns can be expected. On the other hand, strong erosion phenomena such as many mass movements can remove large bodies of soil and archaeological record if present 
and transport their material over a long distance in only a single catastrophic event (Fig. 8b: $\mathrm{t}_{3}-\mathrm{t}_{4}$ ). Archaeological material transported in this way will not contain any patterns related to its primary deposition (Birkeland 1984: 184; Ferring 1986: 264-265; Bintliff and Snodgrass 1988: 508-512; Schaetzl and Anderson 2005: 169, 456).

On depositional surfaces (Fig. 6) sedimentation causes the surface to gradually grow upward (Figs. 7-8a). On such surfaces, the main pathway of soil formation is through upbuilding in contrast to top-down pedogenesis through horizonation. Soil upbuilding relates to natural or anthropogenic additions of mineral or organic material to the soil surface causing upward thickening or growth of the soil profile. Depending on the relationship between the rate and amount of additions and the rate of pedogenesis there can be three main scenarios of soil upbuilding resulting in different types of cumulative soil profiles: developmental upbuilding, cumulisation and soil burial (Birkeland 1984: 184-185; Johnson 1985: 30; Cremeens and Harth 1995: 24; Holliday 2004: 90-96, Fig. 5.9; Schaetzl and Anderson 2005: 456-460, Fig. 12.78).

All three scenarios of cumulative soils are very important from the archaeological point of view. First two scenarios of developmental upbuilding and cumulisation are characteristic for low energy depositional surfaces and result in overthickening of the $B$ and $A$ horizon respectively. In both cases, slow accretion contributes to the burial of archaeological record, which generally positively affects its preservation and stratification. However, because burial is slow the archaeological record will still be quite heavily reworked by surface and pedogenic processes. In the case of cumulisation (Fig. 7b) (see Birkeland 1984: 185; Schaetzl and Anderson 2005: 458-459; Jacobs and Mason 2005: 97-100; Schaetzl 2013: 149), the archaeological record once deposited on the surface will be located within the overthickened A horizon and subjected to dynamic processes characteristic for this topsoil layer. In the case of developmental upbuilding (Fig. 7a) (see Birkeland 1984: 184; Almond and Tonkin 1999: 3; Schaetzl and Anderson 2005: 458; Eger et al. 2012: 499, fig. 4; Lowe and Tonkin 2014: 34-35, Fig. 1), the archaeological remains will at first be subjected to processes characteristic for A horizon formation and later to the processes of the overthickening subsurface $B$ horizon into which they will gradually become incorporated. Homogenization and eventual loss of original sediment structure are characteristic for both $A$ and $B$ horizons (Goldberg and Macphail 2006: Tab. 3.4; Buol et al. 2011: 46; Weil and Brady 2017: 90). Therefore in both scenarios, the relative superposition may be discernible only on the basis of preserved levels of artefacts or/and other durable remains. The levels of different phases of occupation will thus be located within a uniform overthickened B or A horizon. In such circumstances relying on texture and colour differences of the matrix in order to discern stratigraphy of the site will not be effective.

In the case of more rapid gradual additions or sudden additions of a large volume of sediment the soil gradually or rapidly becomes buried and new soil starts to form in the fresh sediment (Fig. 8a) (Schaetzl and Anderson 2005: 459). The presence of buried soils within the stratigraphic sequence of the site is very important because buried soils represent a longer period of past surface stability which is needed for their formation. Generally, the degree of development reflects the relative duration of soil formation ${ }^{6}$, thus weakly developed soils indicate short intervals of surface stability while strongly developed soils indicate longer periods of stability ${ }^{7}$. Burial with new sediment, on the other hand, reflects the instability of the surface, a change in the environmental conditions, and in comparison with soil formation a much shorter period of time. In certain conditions, especially in the case of catastrophic events, large volumes of material can be deposited very suddenly. Even though burial generally aids to the preservation of archaeological record and to its stratification a long period of stability before burial means that archaeological remains have been exposed to reworking by surface and near-surface processes for a longer period of time. Buried soils, especially well-developed ones, may thus contain a palimpsest of remains of subsequent phases of past human activities which will be concentrated in the area of the $A$ horizon (Figs 3 ; $8 a: t_{1}$ ) and heavily reworked. However, in the case of a sudden burial, a simultaneous erosion of the upper part of the soil may occur and is expressed by the absence of the $A$ (and $E$ ) horizon (Fig. $8 a$ : $t_{3}-t_{4}$ ). Identification of this is important as it may have caused the destruction and removal of the archaeological record formed before the deposition of the new sediment. Erosion before burial may also result in welding of the

\footnotetext{
${ }^{6}$ For estimates of the time needed for the development of some of the soil types see for e.g Alexandrovskiy (2007).

${ }^{7}$ Though this rule is complicated in the case of polygenetic soils and processes causing rejuvenation of soil profiles (Johnson and WatsonStegner 1987), such as bioturbation (e.g. Langmaid 1964). All soils at archaeological sites may be considered polygenetic, because there have been at least three stages of development with differences in soil -forming factors (Jenny 1994): (1) initial natural conditions before occupation, (2) conditions durring occupation (addition of the anthropogenic factor; see Schaetzl and Anderson 2005, 317-320; Howard 2017: 58-60), and (3) conditions after occupation.
} 
buried $\mathrm{B}$ horizon and the $\mathrm{B}$ horizon of the soil developing in the new parent material (Fig. 8a: $\mathrm{t}_{3}-\mathrm{t}_{5}$ ). Identification of this is important for the stratigraphic sequence as the welded B horizons are not genetically linked and contemporaneous but subject to the law of superposition. Such welding, on the other hand, can also be caused by the blurring of the buried $A$ horizon through formation processes of the new soil (Fig. 8a: $t_{5}-t_{6}$ ) (Holliday 1988: 530; Ib. 1990: 530; Ib. 2004: 90-91, 140-143, 285, Figs. 5.10, 7.1; Cremeens and Harth 1995: 20-21; Mandel and Bettis 2001: 187; Goldberg and Macphail 2006: 62).

\section{Archaeological remains in soil context and archaeological stratigraphy}

By touching upon only a few types of soil formation and soil geomorphology processes it has been demonstrated that these essentially result in archaeological remains becoming part of soil context. The concept of archaeological remains in soil context (see Anderton 2000) differs from that of archaeological stratigraphic context and represents a problem for the application of archaeological stratigraphic excavations, principles of archaeological stratigraphy and Harris matrix (see Harris 1979; Ibid. 1989). This is because the archaeological stratigraphy is conceptualised as composed especially of events such as deposition, construction, destruction, digging, erosion, etc., and by longer periods of duration which may be represented by interfaces, e.g. living surfaces, as some of the most important units of archaeological stratigraphy (see Harris 1989; Davies 2015). However, the concept does not involve in situ transformations of these types of remains by long-term processes of soil formation.

The excavation of stratigraphic units in the reverse order of their formation is based especially on the observation of differences in texture, colour and composition of layers and the observation of their tridimensional forms and boundaries while artefacts themselves are supposedly not that important in these observations (Harris 1979; Brown and Harris 1993: 10). Stratigraphic units of layers and interfaces represented by their upper boundaries give stratigraphic context to related artefacts and superposition of the units determines their relative temporal relations. Soil horizons differentiated according to colour, texture, etc., also appear as layers in superposition, however, they are not related to deposition, boundaries between them do not represent interfaces known in archaeological stratigraphy and the principle of superposition does not apply to them. Soil horizons reflect long-term pedogenic processes and when belonging to the same soil they are contemporaneous, while artefacts within them are not related to the time reflected by the soil or soil horizons in which they are encountered. In the presence of soils, the observation of artefacts (as well as other types of coarse fragments and durable archaeological features) in the soil context thus becomes crucial for the process of excavation. At a site altered by pedogenesis, these may be the only remains still reflecting the original stratigraphy which is no longer recognizable through the observation of the matrix in which they are encountered (Fig. 2). On the other hand, some post-depositional pedogenic (e.g. bioturbation, Fig. 3) and geomorphic (e.g. erosion; Fig. 8b) processes may produce levels of artefacts and visible remains of cut features which no longer correspond to surfaces or interfaces on which they were originally deposited or from which they were originally dug. Recognition of these types of post-depositional processes is thus crucial from the point of view of the excavation methodology itself as well as types of observations and recordings used which also condition the final interpretation of the site.

Differentiation between features and properties resulting from geogenic, pedogenic and anthropogenic processes and events is needed because all of these cannot be interpreted with the use of the same sets of stratigraphic principles. Therefore, sites formed by a mix of these processes require recognition of at least three different types of stratigraphies which represent different sets of information about them. These are lithostratigraphy, pedostratigraphy, and archaeological stratigraphy (Courty et al. 1989: 31-32, Fig. 2.2; Goldberg and Macphail 2006: 28, Fig. 2.1) (Fig.9; Tab. 1).

On one hand, it is important to recognize lithologic or lithostratigraphic units (see Gasche and Tunca 1983: 327-329; Stein and Holliday 2017: 34-35) which reflect the sedimentation at the site and possible changes in sedimentation environments or processes of sedimentation through time. The processes of sediment deposition $^{8}$ may be natural or anthropogenic and the principle of superposition applies to these depositional units (Fig. 9a). However, in a natural open-air environment, these units will inescapably be more or less reworked by processes of soil formation (Fig. 9b).

A soil with its horizons represents a single pedostratigraphic unit because soil horizons are contemporaneous. The upper boundary of the pedostratigraphic unit corresponds to the top of the topmost soil horizon while

\footnotetext{
${ }^{8}$ For descriptions of various natural and anthropogenic deposition processes relevant at archaeological sites and resulting sediment properties see Karkanas and Goldberg 2019: 21-148.
} 
(a)

rate of sedimentation $>$ rate of pedogenesis

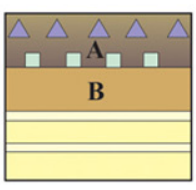

$\mathbf{t}_{1}$

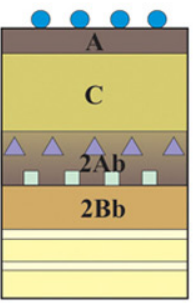

$\mathbf{t}_{2}$

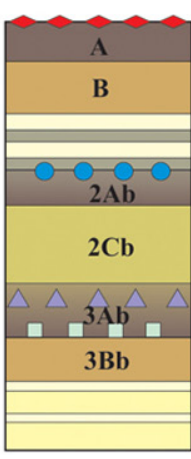

$\mathbf{t}_{3}$

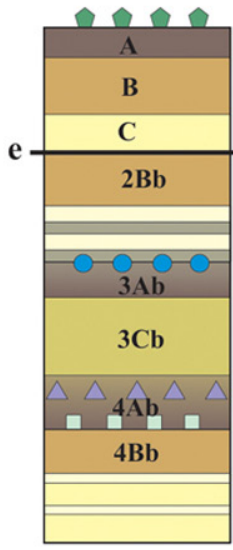

$\mathbf{t}_{4}$

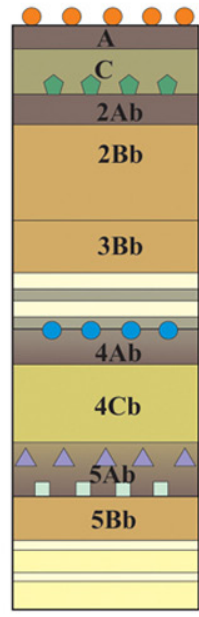

$\mathbf{t}_{5}$

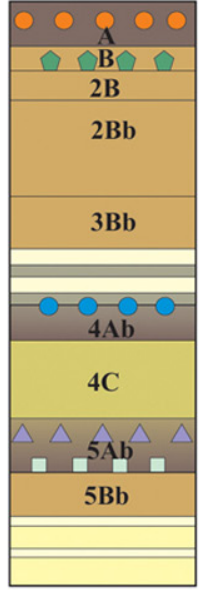

$\mathbf{t}_{6}$

$a_{1}=\square \quad a_{2}=\triangle \quad a_{3}=\bullet \quad a_{4}=\bullet \quad a_{5}=\bullet \quad a_{6}=\bullet$

(b) soil erosion

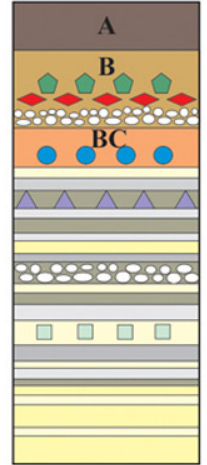

$\mathbf{t}_{1}$

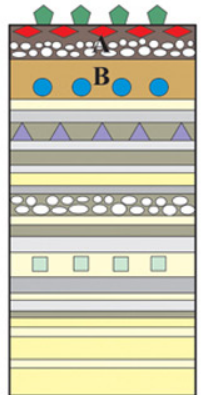

$\mathbf{t}_{2}$

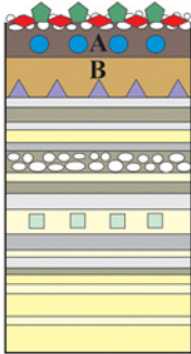

$\mathbf{t}_{3}$

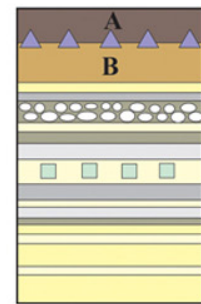

$\mathbf{t}_{4}$

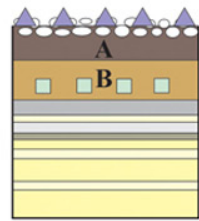

$\mathbf{t}_{5}$

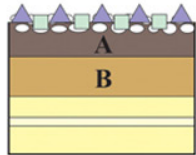

$t_{6}$

FIGURE 8. (a) Hypothetical sequence of buried soils at an archaeological site. Before t1 there were two phases of deposition of archaeological material. The first has sunk into the A horizon due to bioturbation and the second was incorporated into a cumulic A horizon through slow sediment additions. In between t1 and t2 deposition of a thick layer of sediment occurs and during a short period of stability only a weak A horizon forms and some archaeological material is deposited on its surface. This is followed by a sequence of thin sediment depositions in between $\mathrm{t} 2$ and $\mathrm{t} 3$. Initially, the material is incorporated into the soil profile and the A horizon appears cumulic but becomes buried later on. New soil develops in the stratified sediment and archaeological material is deposited on its surface. In between $\mathrm{t} 3$ and $\mathrm{t} 4 \mathrm{the}$ soil is buried by a thick layer of sediment, before the deposition of which erosion occurs and removes the A horizon together with the archaeological material. With further soil development in between $\mathrm{t} 4$ and $\mathrm{t} 5$, the new and the buried $\mathrm{B}$ horizons become welded together. This is followed by a deposition of a layer of sediment burying the soil. In the initial stage of soil formation, an A horizon develops on the new parent material and some archaeological material is deposited on its surface. In between $\mathrm{t} 5$ and $\mathrm{t} 6$ further soil development on a stable surface transforms the buried A horizon into the $B$ horizon of the new soil while the archaeological material is buried by bioturbation. (b) Hypothetical profiles of soil erosion at an archaeological site with weakly developed soil migrating downward into the stratified material. In between t1 and t3 gradual soil erosion causes archaeological artefacts of different phases to be exposed on the surface in the form of a lag concentrate. In between $\mathrm{t} 3$ and $\mathrm{t} 4$, a stronger erosional event removes part of the soil together with archaeological artefacts. In between $\mathrm{t} 4$ and t6 gradual soil erosion again causes artefacts of different phases to be exposed in the form of a lag concentrate. Legend: $\mathrm{t}=$ time of observation; $\mathrm{a}=$ artefacts of different periods; $\mathrm{e}=$ eroded surface (created after the model in Johnson and Balek 1991: Figs. 1-4; Holliday 2004: Fig. 2-4; Schaetzl and Anderson 2005: Fig. 12.78; Lowe and Tonkin 2014: Fig. 1-2). 


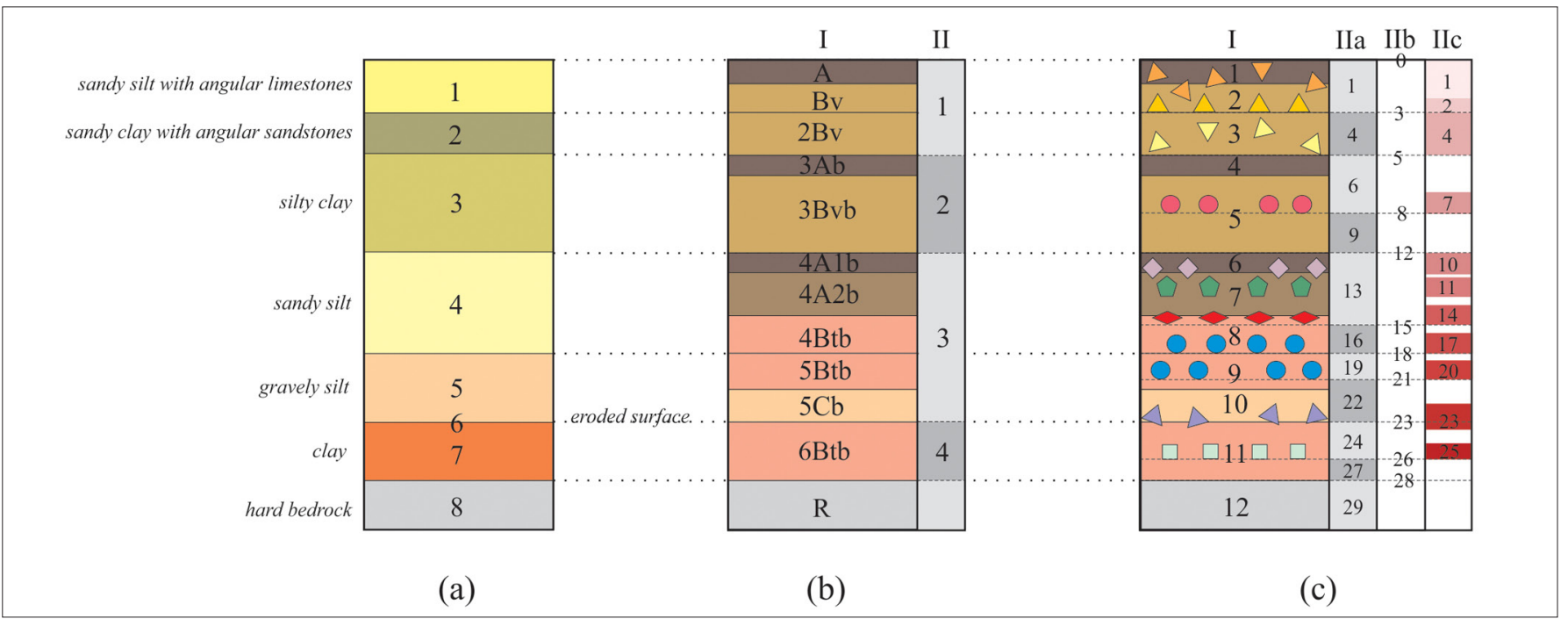

FIGURE 9. A hypothetical example of the same profile in terms of (a) lithostratigraphy, (b) pedostratigraphy, and (c) archaeological stratigraphy in soil context. (a) The profile is differentiated into lithostratigraphic units, determined on the basis of sediment composition, texture and bedding. Each of them represents differences in past sedimentation environments at the observed location in the landscape. The profile is composed of seven lithostratigraphic units and an eroded surface, to which the stratigraphic law of superposition applies. (b) The profile is differentiated on the basis of different soil forming periods at the observed location, which occurred during periods of surface stability in the past landscape. The soils formed in parent materials, which are represented by lithostratigraphic units of the first example. The profile is composed of four pedostratigraphic units (II), which represent four soil forming periods and to which the law of superposition applies, while it does not apply to soil horizons within a particular pedostratigraphic unit. Soil formation, expressed by the development of soil horizons, thus represents post-depositional processes, which reworked the original state of deposition of lithostratigraphic units. Boundaries between these lithostratigraphic units represent lithologic discontinuities reflecting the original geologic stratigraphy of the location. (c) The third example depicts the stratigraphy of the profile from the standpoint of archaeological remains it contains. The differentiation of the profile, marked as I, shows the differentiation based on texture and colour differences of layers in the profile. This differentiation corresponds to the pedological differentiation of the profile and reflects post-depositional processes of soil formation. Interpreting this as a stratigraphic sequence would lead to misunderstanding of the geological, pedological and archaeological record at the location. In the case of an appropriate archaeological differentiation of the profile (II), different phases of sedimentation (IIa), discerned past surfaces or interfaces (IIb) and archaeological remains (IIc) are documented. The last reflects the past human activities, which represent archaeologic discontinuities in the profile. These allow additional past surfaces and phases of sedimentation to be discerned in comparison to those reflected in lithostratigraphic and pedostratigraphic characteristics of the profile. In the interpretation (Table 1) of the archaeological record, past landscape in which it was deposited as well as its post-depositional modifications, all three presented ways of observation must be taken into account (modified after the model in Courty et al. 1989, Fig. 3.3; Goldberg and Macphail 2006, fig. 2.1).

its lower boundary corresponds to the bottom of the lowermost soil horizon, usually, the B horizon, while the C horizon is excluded (Finkl 1980; Cremeens and Harth 1995: 18). If several pedostratigraphic units are present in the profile the law of superposition applies to them and reflects the sequence of periods of landscape stability separated by periods of instability, during which sedimentation occurred (Fig. 9b: II). If the soil has formed in more than one lithologic units their previous stratigraphy might be recognised in the form of lithologic discontinuities. These are thus parts of the soil developed in more than one kind of parent material such as stratified sediments. However, if not reflected by differences in coarse fragments (e.g. gravels and artefacts in Figs: $1 \mathrm{~b}-2$ ) the boundaries between these may be very hard to recognise during macroscopic observations. In soil profile description the presence of lithologic discontinuities is expressed by Arabic numerals added as prefixes to the main horizons, e.g. $B, 2 B, 3 B$ etc., where the $B$ horizon has developed in the uppermost parent material, the $2 \mathrm{~B}$ in the underlying parent material etc. (Scahetzl and Anderson 2005: 37; Ahr et al. 2017). Thus each horizon labelled in this way represents the presence of lithostratigraphy which has been blurred by pedogenic processes (Fig. 9b: I).

The remains of human activities or the anthropogenic deposition of materials may correspond to lithologic discontinuities (Fig. 9c; Tab. 1: SU 4). This will happen especially in cases of distinctly anthropogenic layers of different composition (e.g. sequences of urban sites, sequences of tell settlements etc.). However, there may also be several levels of archaeological remains present within a single natural lithostratigraphic ${ }^{9}$ or pedostrati-

\footnotetext{
${ }^{9}$ In the sense of units belonging to the same natural sedimentation environment, while they can be composed from a hierarchy of layers corresponding to individual depositional events (e.g. individual floods) (Gasche and Tunca 1983: 328-329; Stein 1990: 514-516).
} 
SU $\quad$ INTERPRETATION

$0 \quad$ Modern soil surface.

1 Roman period landfill with material belonging to the end of the 1st century and beginning of 2nd century AD.

2 Remains of a Roman period building with material belonging to the middle and 2./2 of the 1st century AD.

3 The surface of landfill SU 3, on which human activity SU 2 takes place.

$4 \quad$ Roman period landfill with material belonging 1./2 of the 1 st century AD.

$5 \quad$ Soil surface on which human activity SU 4 takes place.

6 Period of sedimentation.

$7 \quad$ Remains of a wooden Iron Age house.

$8 \quad$ The surface on which human activity SU 7 takes place.

$9 \quad$ Period of sedimentation.

Late Bronze Age settlement pottery remains, which have sunk into the A horizon due to bioturbation. The reworked state of the

10 assemblage is actually contemporaneous with the soil surface SU 12. However, because it retains its relative stratigraphic relation with SU 11, it is interpreted as younger than the soil surface SU 12 as well as settlement remains SU 11.

Early Bronze Age settlement pottery remains, which have sunk into the A horizon due to bioturbation. The reworked state of the assemblage is actually contemporaneous with the soil surface SU 12. However, because it retains its relative stratigraphic relation with SU 10, it is interpreted as younger than the soil surface SU 12 and older than settlement remains SU 11.

12 Soil surface on which two phases of human activities SU 11 and 10 took place.

13 Period of sedimentation.

14 Mesolithic hunting camp.

15 The surface on which human activity SU 14 takes place.

16 Period of sedimentation.

17 Upper Palaeolithic station.

18 The surface on which human activity SU 17 takes place.

19 Period of sedimentation.

20 Middle Palaeolithic butchering site.

21 The surface on which human activity SU 20 takes place.

22 Period of sedimentation.

The absence of the A horizon indicates an erosional surface, on which a surface lag deposit of Middle Palaeolithic stone tools is 23 located. The tools indicate human activities which are older than the erosional surface. However, the reworked state of the tool assemblage is contemporaneous with the erosional surface and thus documented with the same SU number.

24 Period of sedimentation.

25 Lower Palaeolithic butchering site.

26 The surface on which human activity SU 25 takes place.

27 Period of sedimentation.

28 The surface of SU 29 or interface between SU 29 and 27.

29 Solid bedrock.

TABLE 1. Interpretation of the archaeological record of the hypothetical profile in Fig. 9c: Ila-c. It can be seen that the complexities introduced into the record by geomorphic and pedogenic processes may defy the law of superposition (see SU 23, 12, 11, 10). The sequence of stratigraphic unit (SU) numbers relates to the temporal interpretation of the record. Some stratigraphic units reflecting human activities (figure 10c: Ilc) no longer correspond to the surfaces or levels on which these activities actually took place. Each phase of human activities is in a simplified manner labelled with only one SU number, while most of them would actually be composed of several different units, related to different types of remains of each phase. 
graphic unit (Fig. 9c; Tab. 1). When these represent the remains of primary deposition they correspond to past surfaces on which human activities had been played out. In such cases, they can also be referred to as archaeologic discontinuities (Fig. 9c; Tab. 1: SU 26\&25, 21\&20, 18\&17, 15\&14, 8\&7) (see for e.g. Fedele 1984: 12). These may be levels with any kind of archaeological remains or consequences of past human activities in situ (e.g. artefacts, anthropogenic layers, hearths, pits etc.).

Archaeological remains represent discontinuities which are present only at archaeological sites or areas with traces of past human activities in the landscape. During the observation of lithostratigraphic or pedostratigraphic profiles away from such areas these types of data about past landscapes which are of relatively fine spatial and temporal scale are not present. Also, during lithostratigraphic and pedostratigraphic profile observations at archaeological sites, many of the archaeologic discontinuities present at the site will not also be present or discernable in the observed profile. This may be because of their small spatial extent (e.g. small features which do not extend into the observed profile) or some other characteristics which make them invisible or hard to spot in the profile (e.g. a level with low artefact density). That is why many types of archaeologic discontinuities may be detected only during meticulous archaeological excavations and ground plan observations.

However, because of post-depositional reworking by geomorphic and pedogenic processes, some levels with anthropogenic remains and features may no longer correspond to original surfaces of past human activities and cannot be treated as archaeologic discontinuities. For example, a level with preserved parts of cut features, upper boundaries of which have been obliterated by bioturbation or erosion (Figs 3 and $8 b$ ) does not correspond to the level from which they had been dug and cannot be treated as an archaeologic discontinuity (Fig. 9c; Tab. 1: SU 10, 11). Similarly, a stone/artefact line/ layer caused by soil erosion no longer corresponds to the original surface of artefact deposition and cannot be considered as an archaeologic discontinuity, though it could be considered as a lithologic discontinuity (Fig. 9c; Tab. 1: SU 23). On the other hand, a stone/artefact line/ layer caused by bioturbation (Fig. 3) cannot be treated either as an archaeologic nor as a lithologic discontinuity but can be treated as a pedologic discontinuity ( $\mathrm{Ahr}$ et al. 2017: 2, 4) to which the law of superposition does not apply.

The interpretation of the archaeological record thus requires the recognition of postdepositional processes which demands an interdisciplinary approach including the observation and recording of geogenic, pedogenic and anthropogenic processes and phenomena. On one hand, such an approach is crucial for the correct interpretation of data about past human activities and the understanding of their environmental context which represent some of the main goals of archaeological science. On the other hand, archaeological data can significantly contribute to the research of processes and phenomena studied by natural sciences such as geology and pedology. In this regard, the archaeological record in the landscape can be seen as a "natural laboratory" which without an interdisciplinary approach remains unthoroughly exploited while each such intervention into it causes a loss of data relevant to several disciplines.

\section{Examples of archaeological remains in soil context}

In the following text, three archaeological sites from Slovenia are briefly presented as potential examples of some of the discussed scenarios of the archaeological remains in soil context. The sites were chosen on the basis of data from their publications and/or field reports. Based on these it seems that the situations observed at these sites could be explained by some of the presented processes resulting in archaeological remains in soil context. However, the presented explanations are not certain as detailed interdisciplinary analyses would be needed to reconstruct their formation history. In this sense, the presented examples, on one hand, point to the potential explanatory power of theoretical models presented and on the other hand serve as a reminder that without an interdisciplinary approach, the excavated remains may never be properly understood and interpreted.

\section{Cogetinci near Lenart}

The site Cogetinci near Lenart (Fig. 10a) is located on a footslope and has the following recorded layer sequence (Fig. 10b). The surface brown layer SU 1 (0,14-0,40 m thick) was the ploughzone with only rare recent finds. In the lower part of the footslope, the ploughzone was underlied by a light yellowish brown loamy layer SU 2 which did not contain any finds and was interpreted as the parent material on which the modern cultivation took place. Under it lay a yellowish-brown silty loam layer SU 7 interpreted as a cultural layer which contained only Late Roman Period finds. This was underlied by a culturally sterile yellow silty loam layer SU 231, interpreted as a geological basis the upper boundary of which represent- 


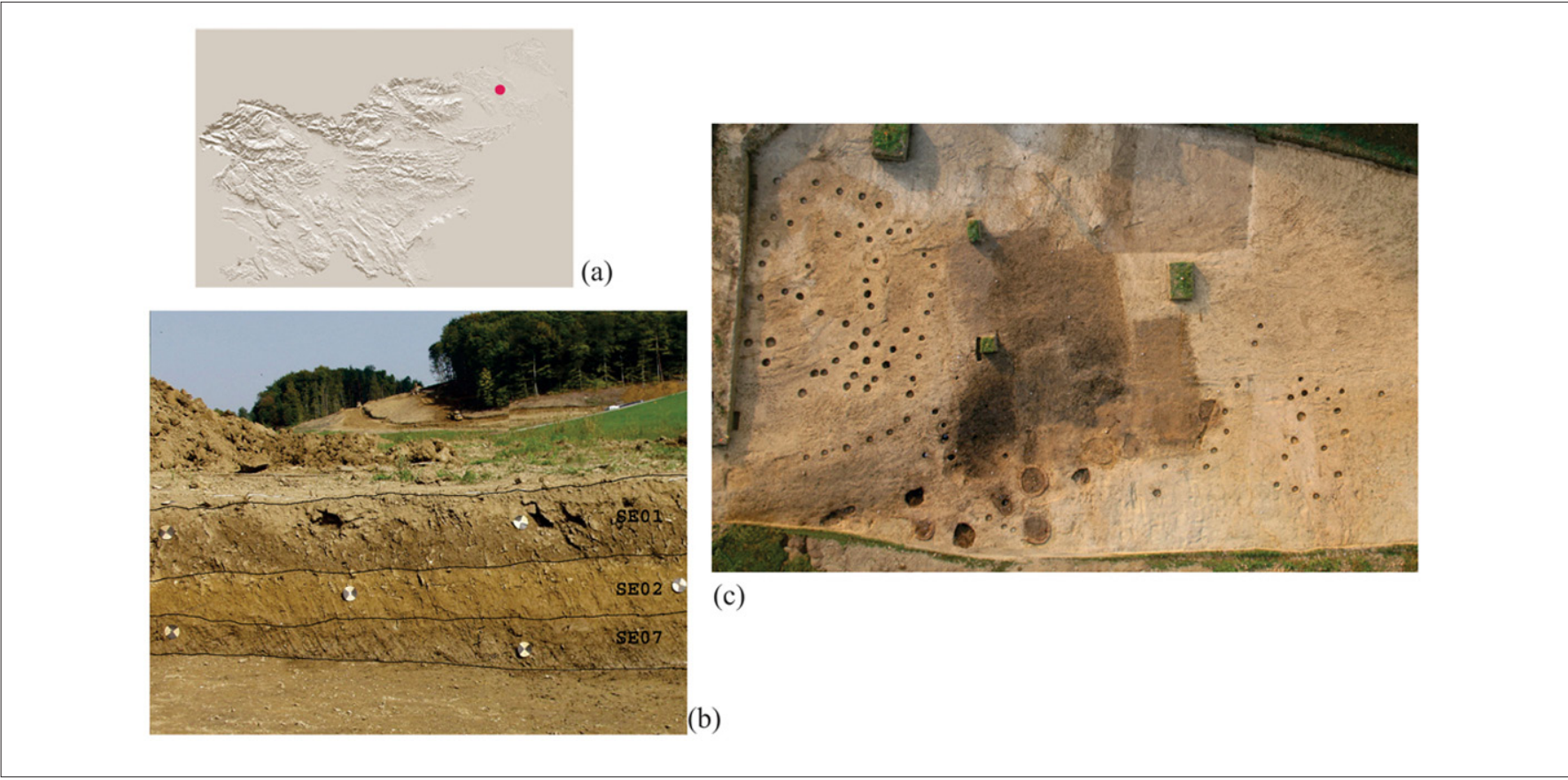

FIGURE 10. (a) Geographic position of site Cogetinci near Lenart (Horvat 2013: sl. 1). (b) Profile of layers at the footslope (Horvat 2007: sl. 3). Plough zone or Ap horizon (SU 1), formed on colluvium (SU $2+1$ ), which buried the soil (SU 7 or Ab horizon and SU 231 or B horizon under it) dating to antiquity. (c) Remains of postholes for timber structures and pottery kilns preserved within the zone of the B horizon and belonging to a potter's workshop from the end of the 4 th and 1st half of the 5th century AD (Horvat 2013: sl. 17).

ed the Late Roman living surface. Postholes, dumping pits and pits for pottery kilns were cut into this layer (Fig. 10c), together representing the remains of a countryside pottery workshop dating to the end of the 4 th and first half of the 5th century (Horvat 2013: 11-12, 88).

The described layer sequence should, in fact, be interpreted as soil horizons representing two pedostratigraphic units (e.g. Fig. 8a: $t_{2}$ ). The "cultural layer" SU 7 represents the A horizon and layer SU 231 the B horizon of a buried soil. This pedostratigraphic unit was buried with material on which new soil began to form, with Ap (SU 1) and B, BC or C (SU 2) horizons together representing one pedostratigraphic unit. Soil burial ${ }^{10}$ in the lower part of the site which isolated and protected the level with Late Roman remains is probably connected with soil erosion and damage of Late Roman remains in the upper part of the site. There the buried A horizon containing Late Roman artefacts was not preserved and modern ploughing reached directly into the SU 231 (Horvat 2013: 12). Thus, the present soil is temporarily transgressive as is typical for soils along a slope (Fig. 6).

\footnotetext{
10 The sedimentation process is not established in the report or the final publication
}

However, the interpretation of the upper boundary of the buried B horizon (SU 231) as a living surface of the Late Roman pottery workshop poses a problem regarding the formation of the observed archaeological context at the site. Namely, the B horizon is a subsurface soil horizon, therefore it could not have been the living surface. The question is, whether the level interpreted as the living surface truly corresponds to the surface of the Late Roman activity and thus represents an archaeologic discontinuity or not? In the case it does, a scenario of developmental upbuilding (Fig. 7a) after the abandonment of the Late Roman pottery workshop should probably be supposed, because the upper boundary of the B horizon in the time of its operation must have been located below the living surface or top of the soil in Late Roman times. On the other hand, a post-depositional reworking of the site by processes in the biomantle (Fig. 3) could also explain the observed soil context of archaeological remains at this site. The fact that all Late Roman artefacts were located at the bottom of the buried A horizon (SU 7) ${ }^{11}$ could correspond well with this scenario. In this

\footnotetext{
${ }^{11}$ Personal communication with the excavator M. Horvat.
} 
case, the upper boundary of the buried B horizon where dug features were preserved and directly above which the artefacts were discovered would not correspond to the actual living surface and thus would not represent an archaeologic discontinuity but instead a pedologic one. In this scenario, the Late Roman living surface would probably be located somewhere within the buried A horizon or correspond more or less to its upper boundary. This would imply that possible features such as earthen floors or fireplaces as well as upper parts of the dug features have been homogenized and destroyed by bioturbation processes, which have also caused artefacts to sink to the bottom of the A horizon and form an artefact line or layer. Knowing which of these two scenarios actually applies to this site would be important for the understanding of its post-depositional reworking, the integrity of discovered remains and estimation of data lost after the original deposition.

\section{Nedelica near Turnišče}

The multiperiod site of Nedelica near Turnišče (Fig. 11a) is located along a gently sloped longitudinal bar deposited by river Mura. The bar is composed of sandy gravel covered with sandy sediment. The sandy to sandy muddy ${ }^{12}$ gravel (4* in Fig. 11: b, c, e) was deposited within the channel and the sandy sediment during occasional floods (Verbič 2006: 2; Šavel \& Sankovič 2013: 6-7). In the geological report (Verbic 2006) there are three main layers recorded along most of the bar and these can be interpreted in terms of pedostratigraphy. Above the sandy gravel deposit $\left(4^{*}\right)$, lay a yellowish to reddish brown gravely sandy mud with iron oxides and signs of pseudogleying (3* in Fig. 11: b, c or SU 303 in Fig. 11: d) corresponding to the Bg horizon. Above it was a muddy sand layer rich in humus which gives it a dark greyish brown colour (2* in Fig. 11: b, c or SU 125 and 304 in Fig. 11: d) and corresponds to an A horizon. These two layers represent a soil formed on sediments of the longitudinal bar and thus a single pedostratigraphic unit. The soil was buried ${ }^{13}$ as indicated by the lighter colour of the top layer (1* in Fig. 11: b, c or SU 1 and 2 in Fig. 11: d) which represents the modern ploughzone or Ap horizon and another pedostratigraphic unit. At the summit of the bar, the situation was somewhat different. There the buried A horizon ( $2^{*}$ in Fig. 11: e and SU 4 (and 3?)

\footnotetext{
${ }^{12}$ Mud or muddy, used in the geological report (Verbič 2006), refers to a mixture of silt and clay fraction.
}

in Fig. 11: $f$ ) was located directly above the sandy gravel (4* in Fig. 11: e and "gravel" in Fig. 12: f) and again under the lighter-coloured modern ploughzone (1* in Fig. 11: e and SU 1 and 2 in Fig. 11: f)(Verbič 2006: 2-4; Šavel 2007: 6-7).

That we are dealing with a buried soil under the modern ploughzone was already suggested in the geological report (Verbič 2006: 4), however, this information was omitted in the final publication of the site (Šavel and Sankovič 2013). Within the layer corresponding to the buried A horizon ( $2 *$ in Fig. 11: b, c, e), the archaeological excavation recorded several different stratigraphic units in different parts of the site (eg. SU 125 and 4 in Fig. 11: d, f). They all have the same texture and dark brownish or brownish-black colour and seem to be differentiated primarily by lateral differences in coarse fragments, namely artefacts and gravels. No contacts and stratigraphic relations are reported between these stratigraphic units. They were interpreted as alluvial when containing gravels and cultural when containing artefacts. Such an example is the "Bronze Age cultural layer" SU 88 which contained a vast amount of Bronze Age pottery including even six whole vessels as well as some stone and pottery tools. However, it also contained some pottery from the Early Iron Age, Roman Period, Early Middle Ages and the Middle Ages. At this level, a number of Bronze Age and modern pits were detected while at the same time this layer "covered" other Bronze Age pits as well as an early medieval pit and an un-dated pit (Šavel and Sankovič 2013: 12, 58, 92-93, 95-96).

If this layer was to be understood as a depositional layer the presented situation of it covering a younger feature as well as its artefact assemblage would not make a lot of sense. However, if seen as archaeological remains in soil context it is possible to try to understand the situation. The mixed artefact assemblage can be understood especially through bioturbation processes within the $A$ horizon. Whole vessels and a vast number of Bronze Age artefacts in the SU 88 are with no doubt related to deposition at the occupation level in that period wile a much lesser number of younger artefacts could be seen as infiltrated finds, probably primarily via bioturbation (Figs. 3 and 4). However, we cannot be certain whether the Bronze Age artefacts represent an archaeologic discontinuity or whether the mixed assemblage recorded as the

\footnotetext{
${ }^{13}$ The lighter colour of the ploughzone indicates new sedimentation, while the increasing thickness of the ploughzone from the top of the dune to its footslope is probably connected with transport of material by ploughing as mentioned in the publication (Šavel and Sankovič 2013: 7) and the geological report (Verbič 2006: 4).
} 


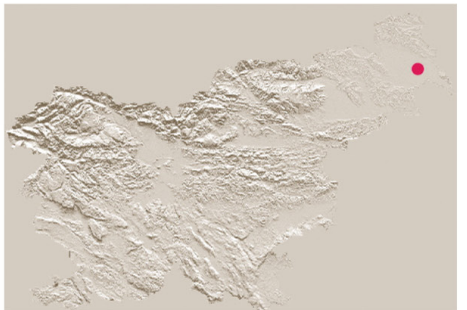

(a)

(b)

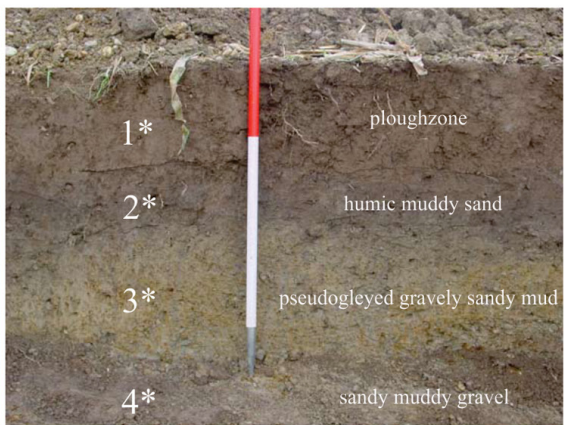

(c)

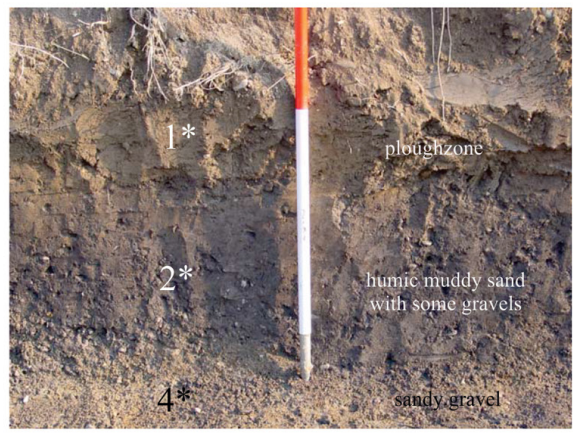

(e)

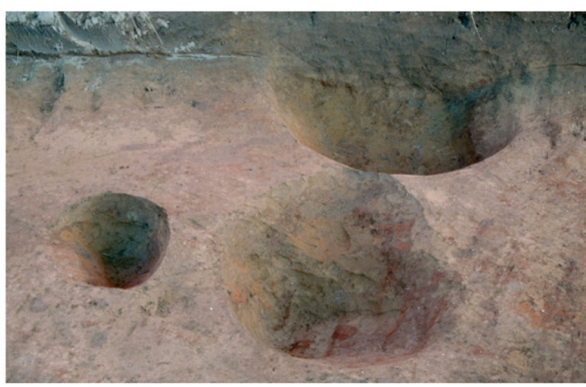

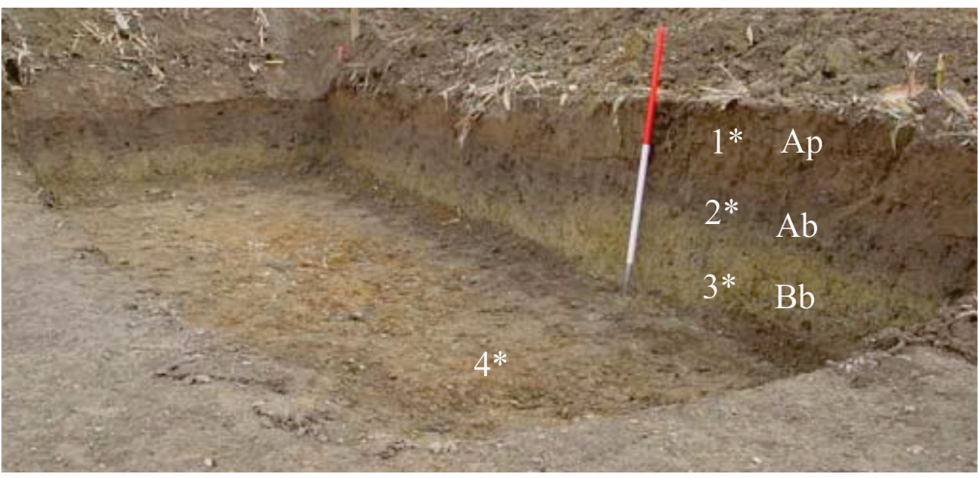

SU 1 - greyish brown sandy silt

SU 2 - greyish brown to yellow redish brown sandy silt

SU 125 - brownish black alluvial layer

SU 303 - yellowish to greyish brown sandy silt

SU 304 - dark brown silty sand with pebble

SU 279 - pit

(d)

SU 4 - dark brown silty sand
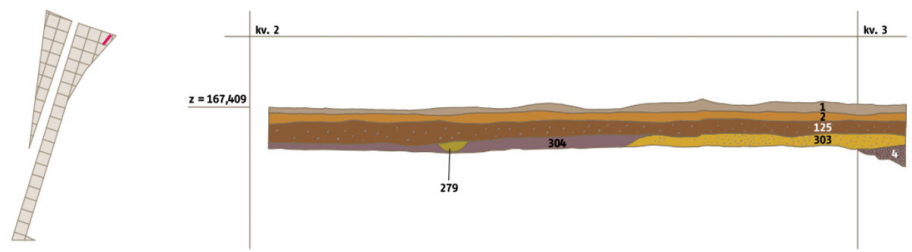

SU 1 - greyish brown sandy silt

SU 2 - greyish brown to yellow redish brown sandy silt

SU 4 - dark brown silty sand alluvial layer

SU 3 - yellow to redish brown sandy silt

gravel
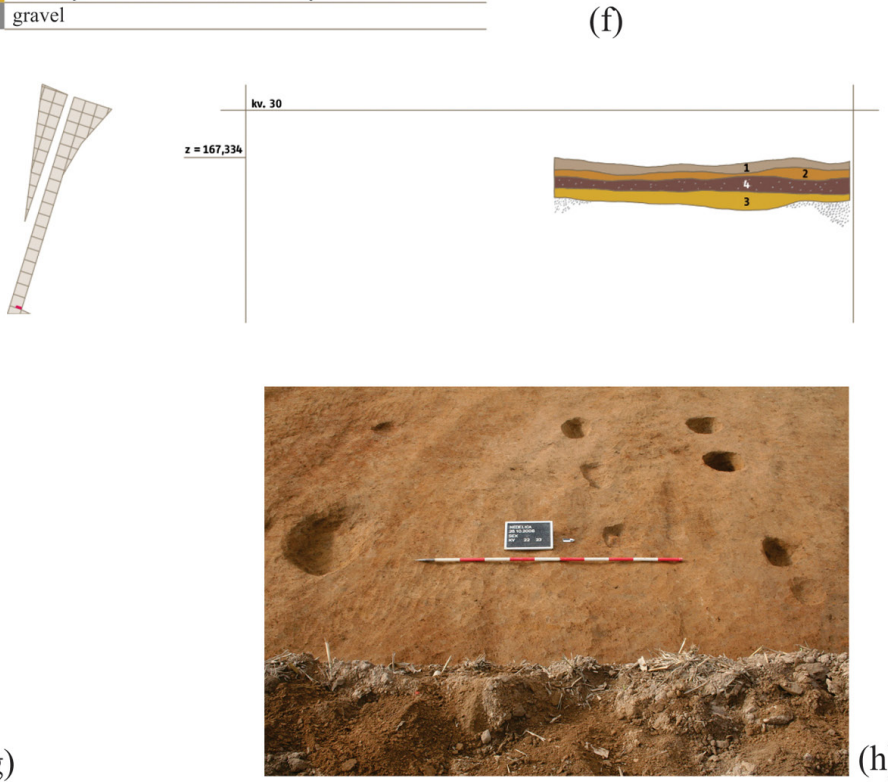

(h)

FIGURE 11. (a) Geographic position of site Nedelica near Turnišče (from Šavel and Sankovič 2013: sl. 1). (b) Profile in trench 1 at the footslope of the longitudinal bar (from Verbič 2006: sl. 2). Layers representing the ploughzone or Ap horizon (1*), buried A horizon (2*) (which could be characterized as an anthropogenic *Au horizon after Howard 2017), buried Bg horizon ( $\left.3^{*}\right)$ and sandy muddy gravel ( $4^{*}$ ) are visible. (c) Detail of the profile in trench 1 shown in b with descriptions according to the geological report (from Verbič 2006: 2, sl. 3). (d) Archaeological drawing and description of the profile in trench 1 shown in b and c (Šavel and Sankovič 2013: 18, sl. 21). (e) Profile in trench 2 at the summit of the longitudinal bar, with descriptions according to the geological report (from Verbič 2006: 2, 3, sl. 6). (d) Archaeological drawing and description of the profile in trench 2 shown in e (Šavel and Sankovič 2013: 18, sl. 22). (g) Shallow remains of Bronze Age postholes, preserved within the buried Bg horizon (under SU 88 or the buried A horizon), while their boundaries in the A horizon are blurred or obliterated (from Šavel and Sankovič 2013: 79). (d) Shallow remains of postholes belonging to a Bronze Age timber structure preserved within the buried Bg horizon (from Šavel and Sankovič: 80). 
SU 88 might represent an artefact line ${ }^{14}$. The remains of a few small whole vessels probably indicate an archaeologic discontinuity and at the same time that activity levels of younger periods indicated by infiltrated artefacts and the occupation levels of the Early Middle Ages and the Middle Ages indicated by features excavated at the site, must have been located somewhere higher within the profile. Namely, in order for the whole Bronze Age vessels to be preserved, they must have been protected by burial, otherwise, they would not have survived anthroturbation caused by subsequent activities and reoccupation of the site during younger periods. However, where the later activity and occupation levels were located is not clear as there were no layers or artefact concentrations recorded which could be interpreted as possible archaeologic discontinuities related to them. It is very possible that they were located within the reach of ploughing and destroyed by it.

The recorded situation regarding features could also be understood in soil context and through processes within the A horizon which cause the blurring of the upper boundaries of dug features (Fig. 3). This would explain why an Early Medieval pit was discovered under the Bronze Age occupational remains or in other words at the level of the Bg horizon, while for reasons indicated above it must have been dug from a level higher than the level of the Bronze Age artefacts within the SU 88. Many Bronze Age pits also discovered under the SU 88 were probably also affected by this kind of blurring, while some were still recognizable in the upper part of the buried A horizon or SU 88. Generally, all over the site, the majority of dug features dating from the Copper Age to the modern period were recognised only at the level of the Bg horizon (Fig. 11g-h). In the cases of most of them, this can probably be best explained by mixing processes within the biomantle or the A horizon (Fig. 3).

\section{Dolenji Podboršt near Trebnje}

On the larger part of the site Dolenji Podboršt (Fig. 12ab), the following layer sequence was recorded (Fig. 12c). Above the limestone bedrock, there was a reddish-yellow loam layer (SU 1003) defined as remains of a terra rosa soil, which in some parts of the site was not present due to erosion. Above it lay a lithostratigraphically uniform yellowish-brown silty clay layer (SU $1002+1001$ ), formed by slow rate colluviation and alluviation process-

\footnotetext{
14 There is no information about the position and orientation of the finds within the SU 88.
}

es. The layer was massive with no recognisable sedimentary structure. The surface dark greyish brown silty clay layer (SU 1000, 0,25-0,35 $\mathrm{m}$ thick) represents the turf and ploughzone (Verbič 2013: 7-13; Masaryk 2013: 31). In terms of pedostratigraphy, this layer sequence represents two units. One is the partly eroded and buried terra rosa soil and the other is the soil above it.

Part of the colluvial-alluvial layer, documented as SU 1001 (Fig. 12c) (mostly 0,25-0,75 m and in parts up to 1,36 m thick) contained archaeological artefacts, spanning from the Lower Palaeolithic to the modern period but with predominant Bronze Age material. It was noted in some parts that pottery sherds predominate especially in the upper and lower parts of the layer while they are scarce in its middle part. Two concentrations of charcoal and several concentrations of pottery sherds reflected different levels within this uniform massive layer which were not recognisable in parts where such fragments were absent. Larger concentrations of pottery sherds were present especially in lower parts of the layer, some of them containing only Bronze Age sherds, many of which belonged to the same vessels. Larger sherds mostly lay in horizontal positions. Cuts of pits and one furnace were also recognised at several different levels within the layer while most of the cuts were recognised only at the level recorded as the SU 1002 and some at the level of the SU 1003 (Fig. 12c-d). In all cases, the recognised cuts represented only lower parts of dug features while their upper parts and surfaces from which they had been dug were not recognisable. This was not only the case with cuts of older periods but also in the case of a telephone cable ditch which was cut and backfilled during the 50 s of the 20th century (!). The main difference between the SU 1001 and SU 1002 (Fig. 12c) was that the latter did not contain artefacts except for infiltrated ones. Namely, the whole site was riddled by burrows (Fig. 12c-d) and nests of small mammals who caused the movement of artefacts within the layers. The infills of their burrows within the SU 1002 sometimes contained artefacts which were usually in a vertical position and their origin was thus ascribed to the SU 1001. A number of pottery sherds displayed damage caused by scratching of small mammals (Fig. 12e), while all of the pottery was generally strongly weathered (Masaryk 2013: 7, 12-13, 22, 24, 25, 29, 31-34, 100-103, fn. 23; Masaryk et al. 2013: 45-46).

The characteristics of this site fit well with the model of developmental upbuilding (Fig. 7a), combined with faunalturbation by small mammals (Fig. 4) and possibly other types of pedoturbations which were already discussed 


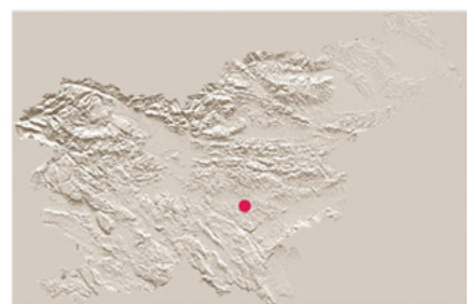

(a)

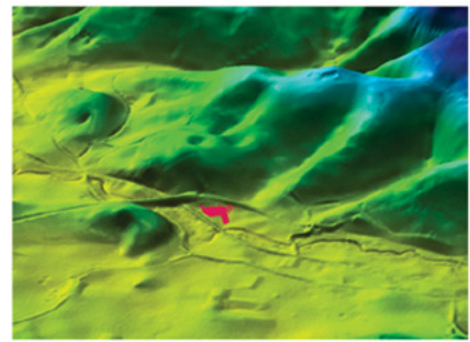

(b) (c)

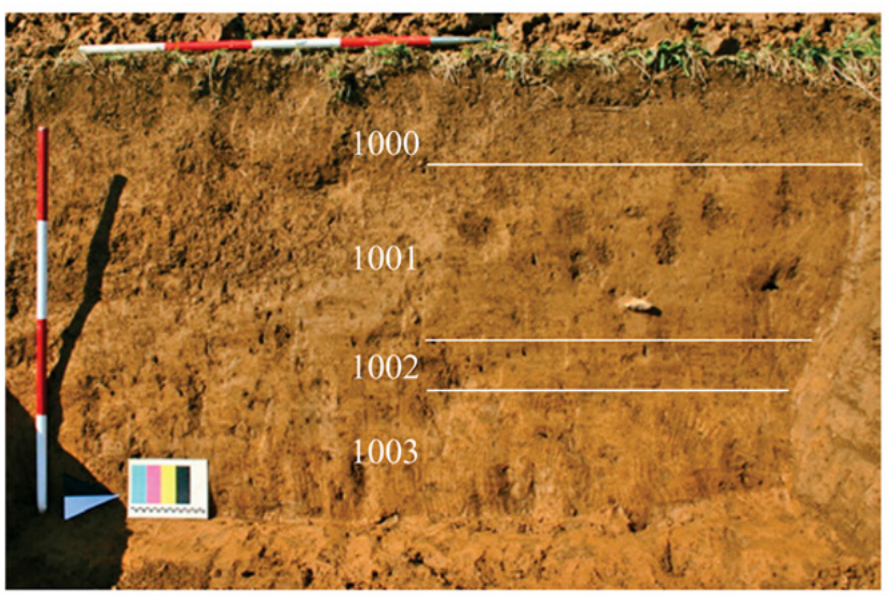

(e)

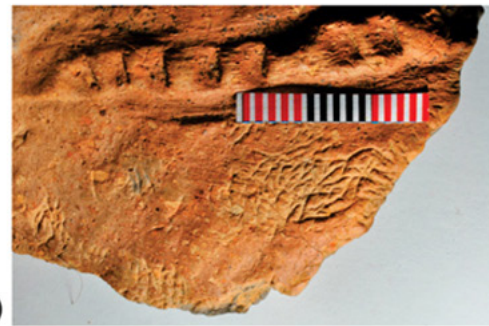

(d)

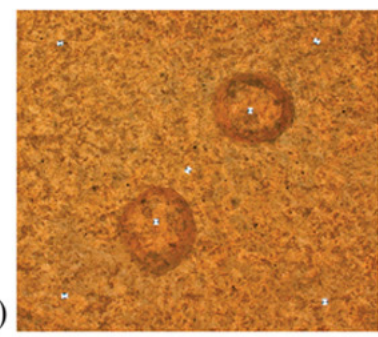

. 


\section{Conclusions}

The majority of the archaeological record is in one way or another part of the soil and therefore affected by soil processes which rework the remains of past human activities studied by archaeologists. During all of our interventions into the subsurface archaeologists constantly observe soils though we rarely see them and record them as such, which may have negative consequences for our understanding of the contexts we observe. Therefore, this paper ${ }^{16}$ was an attempt to shortly discuss the importance that some of the soil formation and soil geomorphology processes have for archaeology. On the basis of this discussion, several broad conclusions can be drawn.

All layers observed during archaeological excavations may not be depositional. Therefore principles of archaeological stratigraphy and archaeological stratigraphic excavations in the reverse order of deposition cannot be applied to all layers differentiated on the basis of their composition, texture and colour. These principles apply only to geogenic or anthropogenic deposits but not to soil horizons which also manifest themselves as distinct layers. In the case of sites altered by soil formation, the archaeological remains are not situated in the archaeological stratigraphic context which is traditionally seen as composed of depositional layers separated by interfaces. Instead, it is situated in soil context where layers are not depositional and borders between them do not represent interfaces. In such circumstances, the recognition of texture and colour differences is important for the recognition of soil horizons to which the principles of pedostratigraphy and not archaeological stratigraphy

\footnotetext{
16 For a somewhat extended discussion of the topic in the Slovene language see Gruškovnjak 2019.
}

apply. These may contain different levels with archaeological remains or blurred archaeological stratigraphy which may be recognised primarily through the observation of inclusions or coarse fragments. Therefore, during the excavation, soil horizons must not be perceived and excavated as whole sediment bodies but instead require slow meticulous excavations and observations focused on the distribution of coarse fragments.

The recognition of soils and archaeological remains in soil context is important for the understanding of some of the site formation processes. In this paper different scenarios of archaeological remains subjected to discussed processes have been depicted in the form of hypothetical illustrations of resulting soil contexts. These may prove useful in the initial evaluation of observed soil contexts at sites altered by soil formation. However, each depiction focusses on a single process, while in reality the archaeological record will always be subjected to a mix of processes, resulting in much more complex situations. Also, a large number of processes and possible scenarios have not been discussed. Furthermore, equifinality must always be taken into account as different sets of processes may result in similar archaeological soil context. Therefore, the depictions of possible scenarios are intended as help in thinking about the possibilities and asking the right questions while the actual formation processes which resulted in the observed archaeological soil context can only be deciphered through interdisciplinary scientific research. 


\section{References}

Ahr, S. W., Nordt, L. C. and Schaetzl, R. J. 2017. Lithologic discontinuities in soils, In: D. Richardson, N. Castree, M. Goodchild, A. Kobayashi, W. Liu, R. A. Marston (eds.), International Encyclopedia of Geography: People, the Earth, Environment and Technology, John Wiley \& Sons, New York. DOI:10.1002/9781118786352.wbieg0816

Alexandrovskiy, A. L. 2007. Rates of soil-forming processes in three main models of pedogenesis, Revista Mexicana de Ciencias Geologicas 24 (2), 293-292.

Almond, P. and Tonkin, P. 1999. Pedogenesis by upbuilding in an extreme leaching and weathering environment, and slow loess accretion, south Westland, New Zeland, Geoderma 92, 1-36.

Anderson, R. and Anderson, S. 2010. Geomorphology: The Mechanics and Chemistry of Landscapes, Cambridge University Press, Cambridge, New York, Melbourne, Madrid, Cape Town, Singapore, Sao Paulo, Delhi, Dubai, Tokyo.

Anderton, J. B. 2000. The Soil-Artifact Context Model: A Geoarchaeological Approach to Paleoshoreline Site Dating in the Upper Peninsula of Michigan, USA, Geoarchaeology: An International Journal 14 (3), 265-288.

Araujo, A. G. M. and Marcelino, J. C. 2003. The Role of Armadillos in the Movement of Archaeological Materials: An Experimental Approach, Geoarchaeology: An International Journal 18 (4), 433-460.

Atkinson, R. J. C. 1957. Worms and Weathering, Antiquity 31, 219-233.

Balek, C. 2002. Buried Artifacts in Stable Upland Sites and the Role of Bioturbation: A Review, Geoarchaeology: An International Journal 17, 41-51.

Barton, C. M., Bernabeu, J., Aura, J. E., Garcia, O. and La Roca, N. 2002. Dynamic Landscapes, Artifact Taphonomy, and Landuse Modeling in the Western Mediterranean, Geoarchaeology: An International Journal 17 (2), 155-190.

Bintliff, J. and Snodgrass, A. 1988. Off-Site Pottery Distributions: A Regional and Interregional Perspective, Current Anthropology 29, 506-513.

Birkeland, P. W. 1984. Soils and Geomorphology, Oxford University Press, New York, Oxford.

Blume, H. P., Brümmer, G. W., Fleige, H., Horn, R., Kandeller, E., Kögel-Knabner, I., Kretzschmar, R., Stahr, K. and Wilke, B. M. 2016. Scheffer/Schachtschabel Soil Science, Springer-Verlag, Heidelberg, New York, Dordrecht, London.

Bocek, B. 1986. Rodent Ecology and Burrowing Behaviour: Predicted Effects on Archaeological Site Formation, American Antiquity 51 (3), 589-603.
Brown III, M. R. and Harris, E. C. 1993. Interfaces in archaeological stratigraphy, In: E. C. Harris, M. R. Brown III and G. J. Brown (eds.), Practices of archaeological stratigraphy, Academic Press, London, San Diego, New York, Boston, Sydney, Tokyo, Toronto, 7-20.

Buol, S. W., Southard, R. J., Graham, R. C. and McDaniel, P. A. 2011. Soil Genesis and Classification, Sixth Edition, Wiley-Blackwell, Chichester.

Canti, M. G. 2003. Earthworm activity and archaeological stratigraphy: a review of products and processes, Journal of Archaeological Science 30 (2), 135-148.

Cremeens, D. and Harth, J. 1995. On Chronostratigraphy, Pedostratigraphy, and Archaeological Context, In: M. E. Collins, B. J. Carter, B. G. Gladfelter and R. J. Southard (eds.), Pedological Perspectives in Archaeological Research, Soil Science Society of America Special Publication 44, Soil Science Society of America, Madison, 15-33.

Courty, D., Goldberg, P., and Macphail, R. 1989. Soils and micromorphology in archaeology, Cambridge Manuals in Archaeology, Cambridge University Press, Cambridge.

Davies, D. 2015. Stratification Theory. Applied Archaeology Series, Guide 40. http://www.bajr.org/BAJRGuides/40. Stratification\%20Theory/40StratificationTheory.pdf

Dunwell, A. J. and Trout, R. C. 1999. Burrowing Animals and Archaeology, Technical Advice Note No. 16, Historic Scotland, Edinburgh.

Eger, A., Almond, P. C. and Condron, L. M. 2012. Upbuilding pedogenesis under active loess deposition in a superhumid, temperate climate - quantification of deposition rates, soil chemistry and pedogenic thresholds, Geoderma 189-190, 491-501.

Fedele, F. G. 1984. Towards an Analytical Stratigraphy: Stratigraphic Reasoning and Excavation, Stratigraphica Archaeologica 1, 7-15.

Ferring, C. R. 1986. Rates of Fluvial Sedimentation: Implications for Archaeological Variability, Geoarchaeology: An International Journal 1 (3), 259-274.

Fey, M. V. and Schaetzl, R. J. 2017. Pedoturbation, In: D. Richardson, N. Castree, M. F. Goodchild, A. Kobayashi, W. Liu and R. A. Marston (eds.), International Encyclopedia of Geography, John Wiley \& Sons, New York. DOI: 10.1002/9781118786352.wbieg0826

Finkl, C. 1980. Stratigraphic Principles as Related to Soil Mantles, Catena 7 (1), 169-194.

Gasche, H. and Tunca, Ö 1983. Guide to Archaeostratigraphic Classification and Terminology: Definitions and Principles, Journal of Field Archaeology 10 (3), 325-335. 
Goldberg, P. and Macphail, R. I. 2006. Practical and Theoretical Geoarchaeology, Blackwell Publishing, Malden, Oxford. Carlton.

Gregorich, E. G., Turchenek, L. W.; Carter M. R. and Angers, D. A. (eds.) 2001. Soil and Environmental Science Dictionary, CRC Press, Boca Raton, London, New York, Washington.

Gruškovnjak, L. 2019. Kratek teoretski pregled vpliva procesov tvorjenja in geomorfologije tal na arheološki zapis / A short theoretical overview of the influence soil formation and soil geomorphology have on the archaeological record, Arheo 36, 7-44.

Hanson, I., Djohari, J., Orr, J., Furphy, P., Hodgson, C., Cox, G. and Broadbridge, G. 2009. New Observations on the Interactions Between Evidence and the Upper Horizons of the Soil, In: K. Ritz, L. Dawson \& D. Miller (eds.), Criminal and Environmental Soil Forensics, Springer Science, New York, 239-251.

Harris, E. C. 1979. The laws of archaeological stratigraphy, World Archaeology 11 (1), 111-117.

Harris, E. C. 1989. Principles of archaeological stratigraphy. Second edition, Academic Press, London, San Diego, New York, Boston, Sydney, Tokyo, Toronto.

Holliday, V. T. 1988. Genesis of Late-Holocene Soil Chronosequence at the Lubbock Lake Archaeological Site, Texas, Annals of the Association of American Geographers 78 (4), 596-610.

Holliday, V. T. 1990. Pedology in archaeology, In: Archaeological Geology of North America, Centennial Special Volume 4, Geological Society of America, Boulder, 525-540.

Holliday, V. T. 2004. Soils in Archaeological Research, Oxford University Press, Oxford, New York, Auckland, Bangkok, Buenos Aires, Cape Town, Chennai, Dar es Salaam, Delhi, Hong Kong, Istanbul, Karachi, Kolkata, Kuala Lumpur, Madrid, Melbourne, Mexico City, Mumbai, Nairobi, São Paulo, Shanghai, Taipei, Tokyo, Toronto.

Horvat, M. 2013. Cogetinci pri Lenartu, Arheologija na avtocestah Slovenije 37, Zavod za varstvo kulturne deiščine Slovenije, Ljubljana. URL: https://www.zvkds.si/sites/ www.zvkds.si/files/uploads/files/publication/37_cogetinci_pri_lenartu.pdf

Howard, J. L. 2017. Anthropogenic Soils. Progress in Soil Science, Springer, Cham.

Huggett, R. J. 2007. Fundamentals of Geomorphology, Second Edition, Ruthledge, Taylor \& Francis Group, London, New York.

Jacobs, P. M. and Mason, J. A. 2005. Impact of Holocene dust aggradation on A horizon characteristics and a carbon storage in loess-derived Mollisols of the Great Plains, USA, Geoderma 125, 95-106.

Jenny, H. 1994. Factors of Soil Formation. A System of
Quantitative Pedology, Dover Publications Inc., New York. Johnson, D. L. 1985. Soil thickness processes, In: P. D. Jungerius (ed.), Soils and Geomorphology. Catena Supplement 6, 29-40.

Johnson, D. L. 1989. Subsurface Stone Lines, Stone Zones, Artifact-Manuport Layers, and Biomantles Produced by Bioturbation via Pocket Gophers (Thommomys Bottae), American Antiquity 54 (2), 370-389.

Johnson, D. L. 1993. Dynamic denudation evolution of tropical, subtropical and temperate landscapes with three tiered soils: Towards a general theory of landscape evolution, Quaternary International 17, 67-78.

Johnson, D. L. 2002. Darwin Would Be Proud: Bioturbation, Dynamic Denudation, and the Power of Theory in Science, Geoarchaeology - An International Journal 17, 7-40. Johnson, D. L. and Balek, C. 1991. The genesis of Quaternary landscapes with stone-lines, Physical Geography 12 (4), 385-395.

Johnson, D. L., Watson-Stegner, D., Johnson, D. N. and, Schaetzl, R. J. 1987. Proisotropic and proanisotropic processes of pedoturbation, Soil Science 143 (4), 278-292.

Johnson, D. L., Domier, J. E. J. and Johnson, D. N. 2005a. Animating the biodynamics of soil thickness using process vector analysis: A dynamic denudation approach to soil formation, Geomorphology 67 (1-2 Spec. Iss.), 23-46.

Johnson, D. L., Domier, J. E. J. and Johnson, D. N. 2005b. Reflections on the Nature of Soil and Its Biomantle, Annals of the Association of American Geographers 95 (1), 11-31.

Johnson, D. L. and Watson-Stegner, D. 1987. Evolution model of pedogenesis, Soil Science 143

Karkanas, P. and Goldberg, P. 2019. Reconstructing Archaeological Sites. Understanding the Geoarchaeological Matrix, John Wiley \& Sons, Oxford.

Langmaid, K. 1964. Some Effects of Earthworm Invasion in Virgin Podzols, Canadian Journal of Soil Science 44 (1), 34-37.

Leigh, D. S. 1998. Evaluating Artifact Burial by Eolian versus Bioturbation Processes, South Carolina Sandhills, USA, Geoarchaeology: An International Journal 13 (3), 309-330.

Lowe, D. J. and Tonkin, P. J. 2014. Unravelling upbuilding pedogenesis in tephra and loess sequences in New Zeland using tephrochronology, In: R. Gilkes and N. Prakongkep (eds.), 19th World Congress of Soil Science, Soil Solutions for a Changing World, 1-6 August 2010, Brisbane, Australia, International Union of Soil Sciences, Crawley, Published on DVD and online http://www.iuss.org.

Mandel, R. D. and Bettis, E. A. III 2001. Use and Analysis of Soils by Archaeologists and Geoscientists: A North American Perspective, In: P. Goldberg, V. T. Holliday and C. R. Ferring (eds.), Earth Sciences and Archaeology, Springer Science+Business Media, New York, 173-204. 
Masaryk, R. 2013. Dolenji Podboršt pri Trebnjem, Arheologija na avtocestah Slovenije 43, Zavod za varstvo kulturne dediščine Slovenije, Ljubljana. URL: https://www. zvkds.si/sites/www.zvkds.si/files/uploads/files/publication/43_dolenji_podborst_pri_trebnjem.pdf

Masaryk, R., Štular, B., Vojaković, P. and Beljkanov Zidanšek, I. 2013. Najdbe in vzorci, In: R. Masaryk 2013, Dolenji Podboršt pri Trebnjem, Arheologija na avtocestah Slovenije 43, Zavod za varstvo kulturne dediščine Slovenije, Ljubljana, 42-56.

McBrearty, S. 1990. Consider the Humble Termite: Termites as Agents of Post-depositional Disturbance at African Archaeological Sites, Journal of Archaeological Science, 17 (2), 111-143.

Norman, S. A., Schaetzl, R. J. and Small, T. W. 1995. Effects of slope angle on mass movement by tree uprooting, Geomorphology 14 (1), 12-27.

Padgett, T. J. 1994. Bioturbation to Bulldozers: The Myth of Undisturbed Sites and Its Implications in Cultural Resource Studies, In: A. C. Goodyear, J. E. Foss and K. E. Sassaman (eds.), Proceedings of the Second International Conference on Pedo-Archaeology. April 6-9, 1994, Anthropological Studies 10, South Carolina Institute of Archaeology and Anthropology, Columbia, 35-39.

Peacock, E. and Fant, D. W. 2002. Biomantle Formation and Artifact Translocation in Upland Sandy Soils: An Example from the Holly Springs National Forests, North Central Mississippi, U.S.A., Geoarchaeology - An International Journal 17, 91-114.

Phillips, J. D. and Lorz, C. 2008. Origins and implications of soil layering, Earth-Science Reviews 89 (3-4), 144-155.

Rolfsen, P. 1980. Disturbance of Archaeological Layers by Processes in the Soil, Norwegian Archaeological Review 13 (2), 111-118.

Schaetzl, R. J. 1986. Complete soil profile inversion by tree uprooting, Physical Geography 7 (2), 181-189.

Schaetzl, R. J. 2013. Catenas and Soils, In: J. Shroder (ed. in chief) and G. A. Pope (ed.), Treatise on Geomorphology Vol 4: Weathering and Soils Geomorphology, Academic Press, San Diego, 145-158.

Schaetzl, R. J. and Anderson, S. 2005. Soils: Genesis and Geomorphology, Cambridge University Press, Cambridge, New York, Melbourne, Madrid, Cape Town, Singapore, São Paulo.

Schaetzl, R. J., Burns, S. F., Johnson, D. L. and Small, T. W. 1988. Tree uprooting: review of impacts on forest ecology, Vegetatio 79, 165-176.

Schaetzl, R. J., Johnson, D. L., Burns, S. F. and Small, T. W. 1989. Tree uprooting: review of terminology, process and environmental implications, Canadian Journal of Forest Research 19 (1), 1-11.
Schaetzl, R. J. and Follmer, L. R. 1990. Longevity of treethrow microtopography: implications for mass wasting, Geomorphology 3 (2), 113-123.

Schiffer, M. B. 1972. Archaeological Context and Systemic Context, American Antiquity 37 (2), 156-165.

Schiffer, M. B. 1973. Cultural formation processes of archaeological record: applications at Joint site, East-Central Arizona, Dissertation, Department of Anthropology, The University of Arizona.

Schiffer, M. B. 1983. Towards the Identification of Formation Processes, American Antiquity 48 (4), 675-706.

Stafford, C. R. and Creasman, S. D. 2002. The Hidden Record: Late Holocene Landscapes and Settlement Archaeology in the Lower Ohio River Valley, Geoarchaeology: An International Journal 17 (2), 117-140.

Stein, J. K. 1983. Earthworm Activity: A Source of Potential Disturbance of Archaeological Sediments, American Antiquity 48 (2), 277-289.

Stein, J. K. 1987. Deposits for Archaeologists, In: M. B. Schiffer (ed.), Advances in Archaeological Method and Theory, Vol. 11. Academic Press, San Diego, new York, Berkeley, Boston, London, Sydney, Tokyo, Torronto, 337395.

Stein, J. K. 1990, Archaeological stratigraphy, In: N. P. Lasca, \& J. Donauhe (eds.), Archaeological Geology of North America, Decade of North American Geology Centennial Special Volume 4, Geological Society of America, 513-523.

Stein, J. K. and Holliday, V. T. 2017. Archaeological stratigraphy, In: A. S. Gilbert (ed.), Encyclopedia of Geoarchaeology, Springer Reference, Dordrecht, Heidelberg, New York, London, 33-39.

Straffin, E. C., Blum, M. D., Colls, A. and Stokes, S. 1999. Alluvial stratigraphy of the Loire and Arroux rivers, Quaternaire 10 (4), 271-282.

Šamonil, P., Schaetzl, R. J., Valtera, M., Goliáš, V., Baldrian, P., Vašíčková, I., Adam, D., Janík, D. and Hort, L. 2013. Crossdating of disturbances by tree uprooting: Can treethrow microtopography persist for 6000 years?, Forest Ecology and Management 307, 123-135.

Šamonil, P., Daněk, P., Schaetzl, R. J., Vašíčková, I. and Valtera, M. 2015. Soil mixing and genesis as affected by tree uprooting in three temperate forests, European Journal of Soil Science 66, 589-603.

Šamonil, P., Valtera, M., Schaetzl, R. J., Adam, D., Vašíčková, I., Daněk, P., Janík, D. and Tejnecký, V. 2016. Impacts of old, comparatively stable, treethrow microtopography on soils and forest dynamics in the northern hardwoods of Michigan, USA, Catena 140, 55-65.

Šavel, I. 2007. Poročilo o arheloškem zaščitnem izkopavanju na arheološkem najdišču Nedelica na trasi AC BeltinciLendava (MP03/2), Maribor, unpublished field report. 
Šavel, I. and Sankovič, S. 2013. Nedelica pri Turnišču, Arheologija na avtocestah Slovenije 39, Zavod za varstvo kulturne dediščine Slovenije, Ljubljana. URL: https://www. zvkds.si/sites/www.zvkds.si/files/uploads/files/publication/39_nedelica_pri_turniscu.pdf

Tandarich, J. P., Darmody, R. G., Follmer, L. R. and Johnson, D. L. 2002. Historical Development of Soil and Weathering Profile Concepts from Europe to the United States of America, Soil Science Society of America Journal 66 (2), 335-346.

Tryon, C. A. 2006. The Destructive Potential of Earthworms on the Archaeobotanical Record, Journal of Field Archaeology 31 (2), 199-202.

Van Nest, J. 2002. The Good Earthworm: Hoe Natural Processes Preserve Upland Archaic Archaeological Sites of Western Illinois, U.S.A., Geoarchaeology: An International Journal 17, 53-90.

Verbič, T. 2006. Poročilo o geološkem ogledu arheološkega najdičča pri Nedelici, Ljubljana, unpublished report.

Verbič, T. 2013. Geomorfologija in geološke razmere na najdišču, In: R. Masaryk, Dolenji Podboršt pri Trebnjem, Arheologija na avtocestah Slovenije 43, Zavod za varstvo kulturne dediščine Slovenije, Ljubljana, 6-13.

Vermeersch, P. M. and Bubel, S. 1997. Postdepositional Artefact Scattering in a Podzol. Processes and Consequences for Late Palaeolithic and Mesolithic Sites, Anthropologie 35 (2), 119-130.

Vidic, N. J., Prus, T., Grčman, H., Zupan, M., Lisec, A., Kralj, T., Vrščaj, B., Rupreth, J., Šporar, M., Suhadolc, M., Mihelič, R. and Lobnik, F. 2015. Tla Slovenije s pedološko karto $v$ merilu $1: 25000$ / Soils of Slovenia with soil map $1: 250$ 000, European Commision, Joint Research Center, Institute for Environment and Sustainability, Luxenburg.
Vrščaj, B. 2013. Tla ali prst? Prispevek k razpravam o rabi izrazov 'tla' in 'prst' $v$ slovenskem poljudnem in strokovnem izrazoslovju, Acta Agriculturae Slovenica 101 (2), 317-328.

Waters, M. R. and Kuehn, D. D. 1996. The Geoarchaeology of Place: the Effects of Geological Processes on the Preservation and Interpretation of Archaeological Record, American Antiquity 61 (3), 483-497.

Weil, R. R. and Brady, N. C. 2017. The Nature and Properties of Soils, Fifteenth Edition, Global Edition, Pearson Education Limited Harlow, London, New York, Boston, San Francisco, Toronto, Sydney, Dubai, Singapore, Hong Kong, Tokyo, Seoul, Taipei New Delhi, Cape Town, Sao Paulo, Mexico City, Madrid, Amsterdam, Munich, Paris, Milan.

Wilkinson, T. J. 1990. Soil development and early land use in the Jazira region, Upper Mesopotamia, World Archaeology 22 (1), 87-103.

Wood, W. R. and Johnson, D. L. 1978. Disturbance Processes in Site Formation, In: M. B. Schiffer (ed.), Advances in Archaeological Method and Theory, Vol. 1, Academic Press, New York, San Francisco, London, 315-381. 